\title{
Mechanisms of Phosphorous Uptake Efficiency of Safflower and Sunflower Grown in Different Soils
}

\author{
Jehad Abbadi $^{1, *}$, Klaus Dittert ${ }^{2}$, Bernd Steingrobe ${ }^{2}$, Norbert Claassen ${ }^{2}$ \\ ${ }^{1}$ Biology Department, College of Science and Technology, Al-Quds University, Jerusalem, Palestine \\ ${ }^{2}$ Department of Plant Nutrition and Yield Physiology, George-August University, Carl-Sprengel Weg 1, Göttingen, Germany \\ *Corresponding author
}

\begin{abstract}
Plant species vary in their phosphorous (P) use efficiency under suboptimal P supplies using different strategies, but the mechanisms are not clearly documented for some alternative plant species. Safflower was considered as low input oil crop, but its P uptake efficiency mechanism was not fully investigated. Therefore P uptake efficiency of safflower was studied as compared to sunflower under semi-controlled conditions in sandy and loamy soils. Both species responded strongly to increasing P supplies in both soils and performed better in loamy soil. Both species had similar agronomic P efficiency in both soils, indicated by similar external P requirement under P-deficient conditions. Under P deficiency, safflower had less relative shoot and root production when they were grown in sandy soils and the opposite was found in terms of loamy soil. Safflower had the disadvantage of less root length and root shoot ratio in both soils under low and high P supplies but had the advantage of higher specific root density, less root radius, and slower shoot growth rate. Under P deficiency in both soil types, both species responded similarly in terms of P influx, depleting P from soil solution and P concentration in shoots. Under high P supply, P influx and P concentration in shoots was less in safflower in both soil types. Safflower was characterized by higher shoot demand on roots for $\mathrm{P}$ under low and high $\mathrm{P}$ supplies in both soil types. Therefore the cause of high root demand on $\mathrm{P}$ in safflower roots at low and high P supplies stems from the low root shoot ratio of safflower at both $\mathrm{P}$ supplies, low $\mathrm{P}$ concentration and low $\mathrm{P}$ influx of safflower at high $\mathrm{P}$ supplies not because of higher shoot growth rate of safflower at low and high $\mathrm{P}$ supplies. Therefore using different measures of utilization efficiency parameters to differentiate plant species and genotypes to superior and inferior could be in some cases misleading.
\end{abstract}

Keywords: P uptake efficiency, alternative crops, safflower, $P$ influx, root shoot ratio, shoot demand

Cite This Article: Jehad Abbadi, Klaus Dittert, Bernd Steingrobe, and Norbert Claassen, "Mechanisms of Phosphorous Uptake Efficiency of Safflower and Sunflower Grown in Different Soils." Research in Plant Sciences, vol. 5, no. 1 (2017): 26-42. doi: 10.12691/plant-5-1-4.

\section{Introduction}

Phosphorus (P) is an essential element for life, serving as an integral component of nucleic acids, lipids and a diverse range of other metabolites [1]. After nitrogen and potassium, $\mathrm{P}$ is quantitatively the most important inorganic nutrient for plant growth and crop productivity, unless supplied as fertilizer [2]. Therefore P is the most determinant nutrient for crop yield in many regions of the world [3]. Because $\mathrm{P}$ is a non-renewable resource, its global reserves is continuously depleting due to extraction by mining day and night [4], making P-fertilizer prices continue increasing $[5,6]$. The availability of $\mathrm{P}$ in soil is low [7] as a result of its fixation, being utilized by organisms forming organic $\mathrm{P}$, and by sorption onto iron and aluminium $[5,8]$. The recovery of fertilizer $\mathrm{P}$ is very low [9], often below $15 \%$ in the first year of application and hardly reaches $50 \%$ after 30 years [10]. Although, in view of limited P resources [5] and serious environmental and economic consequences [11], a considerate use of $\mathrm{P}$ is mandatory to correct nutrient deficiencies [12,13]. P application has been shown to be particularly effective with respect to yield formation in safflower and sunflower
$[14,15,16]$, but in organic farming, where application of inorganic $\mathrm{P}$ fertilizers is not permitted $[17,18]$, the $\mathrm{P}$ availability is not easily increased [19]. Plant species and even cultivars differ in their ability to grow or yield well at suboptimal P supply with remarkable ability to acquire sparingly available soil $\mathrm{P}$, and to utilize internal $\mathrm{P}$ efficiently, that could be explored for future use in crops selection $[5,12,13,15,16]$. In developing countries, where the proportion of less fertile soils is particularly high, it may be difficult to fulfil the nutritional requirements of high-yielding crops [20]. It is thus desirable to aim for efficient use of $P$, both in view of resource limitations and environmental constrains for increasing the production potential on marginal land [21-27]. The use of alternative oil crops that differ in their response to $\mathrm{P}$ nutrition is a possibility to meet the increasing global demand for vegetable oil, and may be possible if phosphorus efficiency mechanisms are illustrated [12,13]. NUE involves various soil and plant mechanisms that contribute to the variability in uptake and utilization of nutrients by different plants in different soils [13,28,29]. Definitions of nutrient efficiency vary greatly [14,21], and in some cases may be even misleading in the quest for identification of mechanisms for enhanced nutrient acquisition and utilization [12,13,30,31,32]. 
Nutrient supply to plants results from interactions between plant roots and soil, depending on the nutrient quantity, nutrient availability and mobility in soil, and uptake kinetics of the root system [5,33,34,35]. As plant roots absorb a nutrient ion, soil solution concentration decreases at the root surface, the equilibrium in soil is thus disturbed, a gradient created, and the adjacent soil release nutrients from the solid soil phase into solution, and/or transport nutrient from the bulk of the soil to the root $[36,37,38]$. Phosphorous uptake by roots from the rhizosphere is affected by desorption of $\mathrm{P}$ from soil particle surface, transport of $\mathrm{P}$ in the soil solution towards the root surface and inflow of $\mathrm{P}$ into root [39,40,41]. These processes depend on soil parameters, and plant parameters as well as the nutrient characteristics [35,42], as a result of interaction between $\mathrm{P}$ availability (quantity and mobility) in soil and the ability of plant to acquire it [13,36,37,38]. A prerequisite of $\mathrm{P}$ uptake is the contact between plant roots and the nutrients in soil, which occur by root growth to the places where nutrients are located and in the same time the transport of nutrients through the soil to the root surface [36]. Therefore, plants develop large root systems to expose large areas of root surface to the soil $[36,43,44,45]$.

The soil is a medium consists of three phases; solid, liquid, and gas, in which the liquid phase is the actual medium for ion transport [46]. Ion diffusion occur from surfaces of solid soil material, to the soil solution towards the root cell, a process that is important for the release of ions located in the soil particle to nourish the plant [36,47]. To make use of diffusion it is important to lower the initial ion concentration of the soil solution around roots in order to create a concentration gradient from soil toward the root to cause diffusive flux, and to disturb the equilibrium between nutrients on the solid phase with those in the liquid phase to cause their release from the matrix into solution $[36,48,49]$.The concentration of nutrient in soil solution, the volume of soil that is filled with water, and the geometry of the soil pore system are the major factors affecting diffusion ability of ions in soil [50]. Plant roots act as a sink for soil nutrients, and the amount of an ion that arrives at a plant root surface depend on the size of root system, length, or surface area, and root distribution in the soil profile [48]. It is the plant that initiates nutrient transport from soil to root [51]. In order to search for low input alternative oil crops and to understand factors affecting $\mathrm{P}$ uptake efficiency among plant species, this study aims to investigate the influence of different $\mathrm{P}$ supplies in two soil types (sandy and loamy) on the components of the uptake efficiency of safflower and sunflower.

\section{Methodology}

\subsection{Experimental Design}

A pot experiment was conducted to evaluate $\mathrm{P}$ uptake efficiency and $\mathrm{P}$ dynamics in the rhizosphere of safflower (Carthamus tinctorius L., variety 'Sabina') and sunflower (Helianthus annuus L., variety 'Peredovick E'), grown in two low P status soil types (loamy and sandy), using three levels of $\mathrm{P}$ supply in a greenhouse having semi-controlled climatic conditions. Before beginning the experiment, field-moist soil samples were sieved to 2-mm particle size, from which, subsamples of soil were air dried and analyzed for extractable $\mathrm{P}$, exchangeable $\mathrm{K}, \mathrm{Mg}$, and $\mathrm{pH}$. Initially, the sandy soil ( $\mathrm{pH} 5.6$ by water extraction) contained $26 \mathrm{mg} \mathrm{kg}^{-1}$ CAL-extractable $\mathrm{P}, 22 \mathrm{mg} \mathrm{kg}^{-1}$ CAL-exchangeable $\mathrm{K}$, and $28 \mathrm{mg} \mathrm{kg}^{-1} \mathrm{NH}_{4}$-acetate exchangeable $\mathrm{Mg}$. The loamy soil (pH 7.0 by water extraction) contained $16.5 \mathrm{mg} \mathrm{kg}{ }^{-1}$ CAL-extractable $\mathrm{P}, 28 \mathrm{mg} \mathrm{kg}^{-1}$ CAL-exchangeable $\mathrm{K}$, and $141 \mathrm{mg} \mathrm{kg}^{-1}$ $\mathrm{NH}_{4}$-acetate exchangeable $\mathrm{Mg}$.

Mitscherlich pots (6 L) were filled with $3 \mathrm{~kg}$ sand $(0$ mg kg ${ }^{-1}$ CAL-extractable P, $3 \mathrm{mg} \mathrm{kg}^{-1}$ CAL-exchangeable $\mathrm{K}$, and $1.8 \mathrm{mg} \mathrm{kg}^{-1} \mathrm{NH}_{4}$-acetate exchangeable $\mathrm{Mg}, \mathrm{pH}$ in water was 7.3) and $3 \mathrm{Kg}$ either sandy or loamy soil. Three $\mathrm{P}$ levels $\left(0,0.2\right.$, and $1.0 \mathrm{~g} \mathrm{P}$ pot $\left.^{-1}\right)$ were added as $\mathrm{Ca}$ $\left(\mathrm{H}_{2} \mathrm{PO}_{4}\right)_{2} \cdot \mathrm{H}_{2} \mathrm{O}$, resulting in solution $\mathrm{P}\left(\mathrm{mg} \mathrm{P} \mathrm{L}^{-1}\right.$ soil solution) content of $0.2,0.6,8.2$ for sandy soil and $0.0,0.2$, 45. 7 for loamy soil in consecutive added P levels. The extractable $\mathrm{P}$ content (mg $\mathrm{P} \mathrm{Kg} \mathrm{soil}{ }^{-1}$ ) of the soil after adding external $\mathrm{P}$ were 25.0, 50.8, 229.5 for sandy soil and 35.4, 54.3, 263.0 for loamy soil in respective $\mathrm{P}$ supplies $\left(0,0.2\right.$, and $\left.1.0 \mathrm{~g} \mathrm{P} \mathrm{pot}^{-1}\right)$. Other nutrients added per pot were $2 \mathrm{~g} \mathrm{~N}$ (as $\mathrm{NH}_{4} \mathrm{NO}_{3}$ ), $3 \mathrm{~g} \mathrm{~K}$ (as $\mathrm{K}_{2} \mathrm{SO}_{4}$ ), $0.8 \mathrm{~g}$ $\mathrm{Mg}$ (as $\mathrm{MgSO}_{4}$ ), micronutrients were added in adequate amount for both species in both soil types (mg pot ${ }^{-1}: 17.5$ B, $2.5 \mathrm{Mo}, 8 \mathrm{Cu}, 50 \mathrm{Mn}$, and $40 \mathrm{Zn}$ ). Three safflower or two sunflower plants were planted in each pot (because sunflower is larger than safflower). The treatments were replicated four times. Four additional pots per each $\mathrm{P}$ level for each soil type were left unplanted as control for the measurement of extractable and soil solution $\mathrm{P}$ concentrations during the experiment without be affected by plant species. The planted and the unplanted pots were watered daily to nearly volumetric soil water content of $35 \%$. The experiment was conducted as a completely randomized design.

\subsection{Harvesting and Analytical Procedures}

The plants were harvested in two harvest times. The plants in one pot of each treatment (plant species and soil type) was harvested in the first harvest after 42 days from sowing for both crops in both soil types, and the rest three pots in each treatment were harvested in the second harvest after 56 days from sowing for both species in both soil types. At each harvest, the soil in each shoot harvested pot was weighed (moist soil with roots), and then soil was cut to two similar parts (also accurately weighed). One part of the soil in each pot was sieved to remove the roots and then was sub-sampled for the following measurements: a soil sample to measure the moisture content of the soil (around 100g), a soil sample for measuring soil solution $\mathrm{P}$ (around 350g), and finally a soil sample for measuring extractable P (around 100g). The second half of the soil of each pot was put in sealed plastic bags and kept at $6^{\circ} \mathrm{C}$ for collecting the roots within 48 hours.

Harvested plants were separated into stems, leaves and roots (half roots per pot were collected). Stems and leaves were measured for fresh and dry weights, then were analyzed for their P contents. The roots in half soil of the pot (precisely weighed) were separated from the soil by washing over a $0.2 \mathrm{~mm}$ sieve, then were preserved in 
plastic bottle at $6^{\circ} \mathrm{C}$ to be measured for their fresh weight and length within 24 hours.

\section{Shoot measurements and $P$ analysis}

At harvest, the dry weight of plant parts were determined after drying at $70{ }^{\circ} \mathrm{C}$ till constant weight. Dried plant materials were grinded to pass a $1.5 \mathrm{~mm}$ sieve, of which, after thorough mixing, a sub-sample of $5 \mathrm{~g}$ was ballmilled to a fine powder. The plant samples were prepared for $\mathrm{P}$ analysis using wet microwave digestion using concentrated tri acid mixture $\left(\mathrm{HNO}_{3}, \mathrm{HClO}_{4}\right.$, and $\mathrm{H}_{2} \mathrm{SO}_{4}$ with a volumetric ratio of $8: 2: 1$ ). Total $\mathrm{P}$ of the plant material digest was measured using colorimetric method (Ammonium-Vanadate-Molybdate) [52].

Measurement of soil solution and extractable $\mathbf{P}$ concentration, $\mathrm{pH}$ and water content

The column displacement method was used [53] to collect the soil solution in order to determine initial soil solution $\mathrm{P}$ concentration. The method permits accurate determination of the unaltered composition of soil solution, in which a sample of moist soil equivalent to $350 \mathrm{~g}$ was packed into a plastic column with a pore in its bottom. Filter paper was placed in the bottom of each soil column to avoid soil particles losses during the collection. The samples were allowed to equilibrate for $24 \mathrm{~h}$; then, deionized water was pumped to each column at a rate of 4 $\mathrm{ml} \mathrm{h}^{-1}$ until the soils reached field capacity water content. The displaced solution was collected tell $25 \mathrm{ml}$ to insure not to collect diluted solution, and then filtered through a $0.20 \mu \mathrm{m}$ filter. The solutions were analyzed for $\mathrm{P}$ by colorimetric method [52]. Soil solution concentration was measured for planted and unplanted pots immediately at the time of each harvest.

To determine solid phase (extractable) P, a 10-g subsample of soil from each pot was air dried then extracted with calcium acetate lactate (CAL) method [54]. Phosphorous concentration in the extracts was determined also using the colorimetric method [52].

The $\mathrm{pH}$ was measured using $0.01 \mathrm{M} \mathrm{CaCl}_{2}$ (1: 2.5 soil: solution ratio). The gravimetric water content was determined in soil samples when soil samples were dried at $105^{\circ} \mathrm{C}$ to constant weight and the water content was calculated as the difference before and after drying.

Root length, root radius, and specific root density measurement

The roots were carefully collected by washing off the soil in a sieve with a $0.2 \mathrm{~mm}$ wide mesh. Roots were cleaned of any foreign materials and then spread on paper towels. The surface moisture on the roots was removed manually by applying uniform pressure using paper towels and finally the root fresh weight (RFW) was recorded. Afterwards, a representative fresh root material of different parts of the root system (upper, middle and apical) was cut in small pieces $(0.5-1 \mathrm{~cm})$. After fine cutting these root portions (1-3 mm), two sub-samples were taken accurately for the root length measurement, using the line intersection method [55]. The fresh weight of the rest of the roots was recorded and then oven-dried and grinded as described above for the shoots. Each fine-cut root sub-sample was dispersed in a known volume of water and an accurately measured volume of aliquot of the root soap was taken and poured in a plastic dish with a grid bottom with lines
$1.25 \mathrm{~cm}$ apart. The total number of root intercepts with the vertical and horizontal grid lines was counted by means of hand tally counter. The root length in the aliquot of the sub-sample was calculated using the following equation: $\mathrm{RL}=(11 / 14) * G D * N$. Where, RL = Root length of the sample in the plastic dish in $\mathrm{cm}$, GD = Grid dimension (1.25 cm grid squares), $\mathrm{N}=$ Number of intercepts.

The root length in the fresh weight subsample was calculated from a volumetric relation between the aliquot and the subsample. The total root length of the plants was obtained from the weight relation between the subsample and the total weight. Assuming that the specific weight of roots is $1 \mathrm{~g} \mathrm{~cm}^{-3}$, the mean root radius $\left(\mathrm{r}_{0}\right)$ was calculated as:

$$
\mathrm{r}_{0}=\sqrt{ }(\text { Root fresh weight }(\mathrm{RFW}) / \pi \text { Root length }(\mathrm{RL}))
$$

The specific root density or root length density $\left(R L_{v}\right)$ was calculated by dividing root length (RL) by the soil volume of the pot and interpreted as $\mathrm{cm}$ root $\mathrm{cm}^{3} \mathrm{soil}^{-1}$.

\section{Shoot growth rate}

This ratio relates the difference in shoot growth between the two harvests divided by the number of days between the two harvests: Shoot growth rate $\left(\mathrm{GR}_{\mathrm{s}}\right)=$ $\ln \left(\mathrm{SW}_{2}-\mathrm{SW}_{2}\right) /\left(\mathrm{t}_{2}-\mathrm{t}_{1}\right)$

Where, $\mathrm{SW}_{1}$ and $\mathrm{SW}_{2}$ are shoot dry weight at the first and the second harvests respectively, and $t_{1}$ and $t_{2}$ are number of days of the plants at the first and the second harvests respectively.

\section{Shoot demand (SD): shoot growth rate in relation to} average root length

This ratio relates the $\mathrm{K}$ acquisition load imposed by shoot growth to each root segment. It was calculated by dividing the shoot growth rate $\left(\mathrm{GR}_{\mathrm{s}}\right)$ by the average root length (aRL) assuming exponential root growth: Shoot growth rate/Root length $\left.(\mathrm{GRs} / \mathrm{RL})=\left(\left(\mathrm{SW}_{2}-\mathrm{SW}_{1}\right) / \mathrm{t}_{2}-\mathrm{t}_{1}\right)\right) \mathrm{X}$ ln $\left(\left(\mathrm{RL}_{2} / \mathrm{RL}_{1}\right) / \mathrm{RL}_{2}-\mathrm{RL}_{1}\right)$. Where $\mathrm{RL}$ is the root length [cm] and SW is the shoot dry weight [g] at two harvest dates $\left(\mathrm{t}_{2}-\mathrm{t}_{1}\right)$.

\section{Net $P$ influx}

The influx is the net amount of a nutrient that is taken up per unit root length (or root surface area) per unit time. Since direct measurement of the influx is not possible, only an average influx can be calculated for a given time period. At least two harvests are needed in which the nutrient content and root length of the plants are known. Assuming that the roots of young plants show exponential growth, the average influx was calculated [56]: In $=\left[\left(\mathrm{U}_{2^{-}}\right.\right.$ $\left.\left.\mathrm{U}_{1}\right) \mathrm{X} \ln \left(\mathrm{RL}_{2} / \mathrm{RL}_{1}\right)\right] /\left[\left(\mathrm{t}_{2}-\mathrm{t}_{1}\right) /\left(\mathrm{RL}_{2}-\mathrm{RL}_{1}\right)\right]$. Where In is the influx, $\mathrm{U}$ is the shoot $\mathrm{P}$ content [mol] at two harvest dates $\left(t_{2}-t_{1}\right)$ related to the root length between the two harvests $\left(\mathrm{RL}_{2}-\mathrm{RL}_{1}\right)$.

\subsection{Statistical Analysis}

All statistical analyses were carried out using SAS (SA Institute Inc., Cary, USA, Release 8.02, 2001). Comparisons of means between different treatments were carried out using the GLM procedure considering a fully randomized design. With multiple t-test, the Bonferoni procedure was employed in order to maintain an experiment-wise $\alpha$ of $5 \%$. 


\section{Results}

\subsection{Growth and Morphology}

Both species responded strongly to increasing P supply in terms of fresh weight of all growth parameters (Table 1). Both species produced significantly higher fresh weight of all growth parameters when were grown in loamy soil as compared to sandy soil. At zero added P supply, both species showed better relative growth in terms of fresh weight of all growth parameters when grown in sandy soils in comparison with that grown in loamy soils. Under very low $\mathrm{P}$ supply, safflower leaves were reduced more than stems in both soil types, the same response was observed for sunflower grown in sandy soil but the opposite was recorded in loamy soil. Comparing both species under low $\mathrm{P}$ supply (0 and $\left.0.2 \mathrm{~g} \mathrm{P} \mathrm{pot}^{-1}\right)$, relative leaves, stems, shoot, root, and total fresh weight of safflower was higher than that of sunflower, the only exception was recorded for root fresh weight in loamy soil at $0.2 \mathrm{~g} \mathrm{P} \mathrm{pot}^{-1}$.

The dry weight of the plant parts of both species responded strongly to increasing $P$ supply (Table 2). Under low $\mathrm{P}$ supplies, safflower leaves dry weights were affected more than stems in both soil types, and for sunflower plants when were grown in sandy soils only. Both species performed better in terms of dry weight production of shoot components when were grown in loamy soil as compared to sandy soils, while the opposite was found in sunflower plants when were grown with no added $\mathrm{P}$ supply. The relative shoot dry weight production was found not significantly different in both species under zero added $\mathrm{P}$ supply in sandy soil, while under $0.2 \mathrm{~g} \mathrm{P}^{\mathrm{P}} \mathrm{pt}^{-1}$, safflower was found superior as compared to sunflower grown in sandy soil. The same figure in loamy soil proved the superiority of safflower as compared to sunflower in terms of relative dry weight production at both 0 and $0.2 \mathrm{~g} \mathrm{P} \mathrm{pot}^{-1}$.

Table 1. Effect of $P$ supply on fresh matter $\left(\mathrm{g} \mathrm{pot}^{-1}\right)$ of safflower and sunflower as absolute value (without brackets) and relative values (between brackets). For a given species and a given soil type, means within each column followed by the same letter are not significantly different, * indicates significant difference for a given plant species and a given $P$ level within soil types. $P<0.05, n=3$

\begin{tabular}{|c|c|c|c|c|c|c|c|c|c|c|}
\hline \multirow{2}{*}{$\begin{array}{l}\text { P supply } \\
\left(\mathrm{g} \mathrm{pot}^{-1}\right)\end{array}$} & \multicolumn{2}{|c|}{ Leaves } & \multicolumn{2}{|c|}{ Stem } & \multicolumn{2}{|c|}{ Shoot } & \multicolumn{2}{|c|}{ Fine roots } & \multicolumn{2}{|c|}{ TFW } \\
\hline & Sandy & Loamy & Sandy & Loamy & Sandy & Loamy & Sandy & Loamy & Sandy & Loamy \\
\hline \multicolumn{11}{|l|}{ Safflower } \\
\hline 0 & $\begin{array}{c}3.9 \mathrm{~B} * \\
(32.5)\end{array}$ & $\begin{array}{l}4.8 \mathrm{C} \\
(9.8)\end{array}$ & $\begin{array}{c}2.3 \mathrm{~B} * \\
(46.9)\end{array}$ & $\begin{array}{l}2.7 \mathrm{C} \\
(13.1)\end{array}$ & $\begin{array}{c}6.2 \mathrm{~B} * \\
(36.5)\end{array}$ & $\begin{array}{c}7.6 \mathrm{C} \\
(10.9)\end{array}$ & $\begin{array}{l}2.3 \mathrm{~A} \\
(54.8)\end{array}$ & $\begin{array}{l}2.6 \mathrm{~B} \\
(13.5)\end{array}$ & $\begin{array}{c}7.5 \mathrm{~B} * \\
(38.9)\end{array}$ & $\begin{array}{l}9.0 \mathrm{C} \\
(10.9)\end{array}$ \\
\hline 0.2 & $\begin{array}{c}8.0 \mathrm{AB} * \\
(40.0)\end{array}$ & $\begin{array}{l}24.0 \text { B } \\
(49.0)\end{array}$ & $\begin{array}{l}4.1 \mathrm{~A} * \\
(83.7)\end{array}$ & $\begin{array}{c}10.5 \text { B } \\
(51)\end{array}$ & $\begin{array}{c}12.2 \mathrm{BA} * \\
(71.8)\end{array}$ & $\begin{array}{l}34.5 \text { B } \\
(49.6)\end{array}$ & $\begin{array}{l}4.0 \mathrm{~A}^{*} \\
(95.2)\end{array}$ & $\begin{array}{l}11.1 \mathrm{~A} \\
(57.8)\end{array}$ & $\begin{array}{c}14.6 \mathrm{BA} * \\
(75.6)\end{array}$ & $\begin{array}{l}41.0 \mathrm{~B} \\
(49.7)\end{array}$ \\
\hline 1.0 & $12.0 \mathrm{~A} *$ & $49.0 \mathrm{~A}$ & $4.9 \mathrm{~A} *$ & $20.6 \mathrm{~A}$ & $17.0 \mathrm{~A} *$ & $69.6 \mathrm{~A}$ & $4.2 \mathrm{~A} *$ & 19.2 A & $19.3 \mathrm{~A} *$ & $82.5 \mathrm{~A}$ \\
\hline \multicolumn{11}{|c|}{ Sunflower } \\
\hline 0 & $\begin{array}{c}27.7 \text { B * } \\
(32.0)\end{array}$ & $\begin{array}{l}7.7 \mathrm{C} \\
(3.6)\end{array}$ & $\begin{array}{c}28.5 \text { B * } \\
(34.7)\end{array}$ & $\begin{array}{l}6.6 \mathrm{C} \\
(2.2)\end{array}$ & $\begin{array}{c}56.7 \mathrm{~B} * \\
(33.6)\end{array}$ & $\begin{array}{c}14.3 \mathrm{C} \\
(2.8)\end{array}$ & $\begin{array}{c}21.6 \mathrm{~B} * \\
(52.6)\end{array}$ & $\begin{array}{l}6.1 \mathrm{C} \\
(4.6)\end{array}$ & $\begin{array}{c}69.1 \mathrm{~B} * \\
(35.7)\end{array}$ & $\begin{array}{c}17.8 \mathrm{C} \\
(3.0)\end{array}$ \\
\hline 0.2 & $\begin{array}{c}28.2 \mathrm{~B} * \\
(32.6)\end{array}$ & $\begin{array}{l}82.0 \mathrm{~B} \\
(38.2)\end{array}$ & $\begin{array}{c}30.7 \text { B * } \\
(37.4)\end{array}$ & $\begin{array}{c}105.6 \mathrm{~B} \\
(34.5)\end{array}$ & $\begin{array}{l}58.4 \text { B * } \\
(34.6 \%)\end{array}$ & $\begin{array}{c}187.6 \mathrm{~B} \\
(36.0)\end{array}$ & $\begin{array}{c}23.4 \mathrm{~B} * \\
(56.9)\end{array}$ & $\begin{array}{l}80.6 \text { B } \\
(61.0)\end{array}$ & $\begin{array}{c}72.3 \mathrm{~B} * \\
(37.0)\end{array}$ & $\begin{array}{c}232.0 \mathrm{~B} \\
(38.8)\end{array}$ \\
\hline 1.0 & $86.6 \mathrm{~A} *$ & $214.5 \mathrm{~A}$ & $82.2 \mathrm{~A} *$ & $306.2 \mathrm{~A}$ & $168.8 \mathrm{~A} *$ & $520.7 \mathrm{~A}$ & $41.1 \mathrm{~A} *$ & $132.1 \mathrm{~A}$ & 195.3 A * & 598.6 A \\
\hline
\end{tabular}

Table 2. Effect of $P$ supply on dry matter $\left(\mathrm{g} \mathrm{pot}^{-1}\right.$ ) of safflower and sunflower as absolute value (without brackets) and relative values (between brackets). For a given species and a given soil type, means within each column followed by the same letter are not significantly different, * indicates significant difference for a given plant species and a given $P$ level within soil types. $P<0.05, n=3$

\begin{tabular}{|c|c|c|c|c|c|c|}
\hline \multirow{2}{*}{$\begin{array}{l}\text { P supply } \\
\left(\mathrm{g} \mathrm{pot}^{-1}\right)\end{array}$} & \multicolumn{2}{|c|}{ Leaves } & \multicolumn{2}{|c|}{ Stem } & \multicolumn{2}{|c|}{ Shoot Dry Weight } \\
\hline & Sandy & Loam & Sandy & Loam & Sandy & Loam \\
\hline 0 & $\begin{array}{c}0.67 \text { C * } \\
(33.0)\end{array}$ & $\begin{array}{c}0.86 \mathrm{C} \\
(11.7)\end{array}$ & $\begin{array}{c}0.56 \mathrm{~A} * \\
(56.6)\end{array}$ & $\begin{array}{c}0.65 \text { C } \\
(13.9)\end{array}$ & $\begin{array}{c}1.23 \text { B * } \\
(40.7)\end{array}$ & $\begin{array}{l}1.51 \mathrm{C} \\
(12.5)\end{array}$ \\
\hline 1.0 & $2.03 \mathrm{~A} *$ & $7.37 \mathrm{~A}$ & $0.99 \mathrm{~A} *$ & $4.69 \mathrm{~A}$ & $3.02 \mathrm{~A} *$ & $12.06 \mathrm{~A}$ \\
\hline \multicolumn{7}{|l|}{ Sunflower } \\
\hline 0 & $\begin{array}{c}3.65 \text { B * } \\
(38.2)\end{array}$ & $\begin{array}{c}1.38 \mathrm{C} \\
(6.1)\end{array}$ & $\begin{array}{c}2.70 \mathrm{~B} * \\
(55.8)\end{array}$ & $\begin{array}{c}0.64 \mathrm{C} \\
(2.9)\end{array}$ & $\begin{array}{c}6.35 \mathrm{~B} * \\
(44.1)\end{array}$ & $\begin{array}{c}2.02 \mathrm{C} \\
(4.5)\end{array}$ \\
\hline 0.2 & $\begin{array}{c}3.91 \text { B * } \\
(40.9)\end{array}$ & $\begin{array}{c}10.06 \mathrm{~B} \\
(44.3)\end{array}$ & $\begin{array}{c}2.86 \mathrm{AB} * \\
(59.1)\end{array}$ & $\begin{array}{l}8.45 \text { B } \\
(38.6)\end{array}$ & $\begin{array}{c}6.77 \mathrm{~B} * \\
(47.0)\end{array}$ & $\begin{array}{c}18.51 \mathrm{~B} \\
(41.5)\end{array}$ \\
\hline 1.0 & $9.55 \mathrm{~A} *$ & $22.73 \mathrm{~A}$ & $4.84 \mathrm{~A} *$ & $21.88 \mathrm{~A}$ & $14.39 \mathrm{~A} *$ & $44.61 \mathrm{~A}$ \\
\hline
\end{tabular}




\section{Growth rate of roots and shoot}

Root growth rate (cm root/ day) for both species grown in sandy soil were statistically similar in different $\mathrm{P}$ supplies (Table 3). In loamy soils, root growth rate (GRr) of safflower increased significantly at low $\mathrm{P}$ supplies, while in sunflower the significantly lowest value was found in the lowest P supply. Comparing the same species at different soil types, safflower showed similar values in both low and high P supplies, but in intermediate P levels, GRr was significantly higher when safflower was grown in sandy soil as compared to loamy soil. Sunflower GRr was similar in both soil types at both intermediate and high $\mathrm{P}$ supplies, while at low $\mathrm{P}$ levels, plants grown in sandy soil had significantly higher values than that grown in loamy soil.

Shoot growth rate (g TDW/ day) of safflower plants was found the highest in plants grown in intermediate $\mathrm{P}$ supplies in both soils. In loamy soil, shoot growth rate (GRs) of safflower was similar in both low and high $P$ supplies, while in sandy soil, this figure was found lower in plants grown in high $\mathrm{P}$ supply as compared to low $\mathrm{P}$ supply. Sunflower GRs didn't change significantly with increasing $\mathrm{P}$ supply when plants were grown in sandy soil, while the same figure in loamy soil was significantly similar in intermediate and high $\mathrm{P}$ supplies, while at low $\mathrm{P}$ level the value was significantly lower than the other $\mathrm{P}$ levels (Table 3). GRr and GRs for the same plant species responded similarly in different soil types; both traits were found inferior in safflower as compared to sunflower in sandy soil in both low and high $\mathrm{P}$ levels but not in the intermediate level (both species are similar). In loamy soil both traits were similar in both species at low $\mathrm{P}$ supply but safflower was interior as compared to sunflower at intermediate and high supplies.

\subsection{P Uptake Efficiency Parameters}

Uptake efficiency parameters discussed in this investigation where those related to plant (root parameters) and those related to soil. Root parameters influencing the $\mathrm{P}$ uptake are: root length, root diameter, specific root density, $\mathrm{P}$ influx in roots, shoot demand for $\mathrm{P}$ on roots, and root shoot ratio. Soil parameters include soil solution $\mathrm{P}$, extractable $\mathrm{P}$, and $\mathrm{pH}$.

Root length (RL), specific root density (RLv), and radius $\left(\mathrm{r}_{0}\right)$

Safflower root length (cm pot $\left.{ }^{-1}\right)$ increased with increasing external $\mathrm{P}$ supply in both soil types (Figure 1), and it was longer in loamy soil than that in sandy soil (the difference at 0 added $\mathrm{P}$ was not significant). Roots of sunflower plants grown in loamy soil increased in length significantly with progressive $\mathrm{P}$ supplies, while that grown in sandy soils were longer at the highest $\mathrm{P}$ supply $(1.0 \mathrm{~g} \mathrm{P}$ pot $\left.^{-1}\right)$, and shortest at the intermediate $\mathrm{P}$ supply $(0.2 \mathrm{~g} \mathrm{P}$ pot $^{-1}$ ), but under 0 added $P$, root length were intermediate. At 0 added $\mathrm{P}$ level, sunflower grown in sandy soils enlarged the root length more than that in loamy soil, while the opposite was recorded at 0.2 and $1.0 \mathrm{~g} \mathrm{P} \mathrm{pot}^{-1}$.

Table 3. Effect of $P$ supply on relative root growth rate (cm root/ day), relative shoot growth rate (g TDW/ day) for safflower and sunflower. For a given species and a given soil type, means within each column followed by the same capital letter are not significantly different, means in the same soil type and the same $P$ level and different plant species followed by the same small letter are not significantly different, * indicates significant difference for a given plant species and a given $P$ level within soil types. $P<0.05, n=3$

\begin{tabular}{|c|c|c|c|c|}
\hline \multirow{2}{*}{$\begin{array}{l}\text { P supply } \\
\left(\mathrm{g} \mathrm{pot}^{-1}\right)\end{array}$} & \multicolumn{2}{|c|}{ Root growth rate (cm root/ day) } & \multicolumn{2}{|c|}{ Shoot growth rate (g TDW/ day) } \\
\hline & Sandy & Loam & Sandy & Loam \\
\hline 0 & 0.104 BA, b & $0.118 \mathrm{~A}, \mathrm{a}$ & $0.106 \mathrm{~B}, \mathrm{~b}$ & $0.081 \mathrm{~B}, \mathrm{a}$ \\
\hline 0.2 & $0.193 \mathrm{~A}, \mathrm{a}$ * & $0.098 \mathrm{~A}, \mathrm{~b}$ & $0.184 \mathrm{~A}, \mathrm{a} *$ & $0.149 \mathrm{~A}, \mathrm{~b}$ \\
\hline \multicolumn{5}{|c|}{ Sunflower } \\
\hline 0 & $0.183 \mathrm{~A}, \mathrm{a} *$ & $0.081 \mathrm{~B}, \mathrm{a}$ & $0.180 \mathrm{~A}, \mathrm{a} *$ & $0.095 \mathrm{~B}, \mathrm{a}$ \\
\hline 0.2 & $0.187 \mathrm{~A}, \mathrm{a}$ & $0.158 \mathrm{~A}, \mathrm{a}$ & $0.177 \mathrm{~A}, \mathrm{a}$ & $0.170 \mathrm{~A}, \mathrm{a}$ \\
\hline 1.0 & $0.215 \mathrm{~A}, \mathrm{a}$ & $0.179 \mathrm{~A}, \mathrm{a}$ & $0.207 \mathrm{~A}, \mathrm{a}$ & $0.203 \mathrm{~A}, \mathrm{a}$ \\
\hline
\end{tabular}
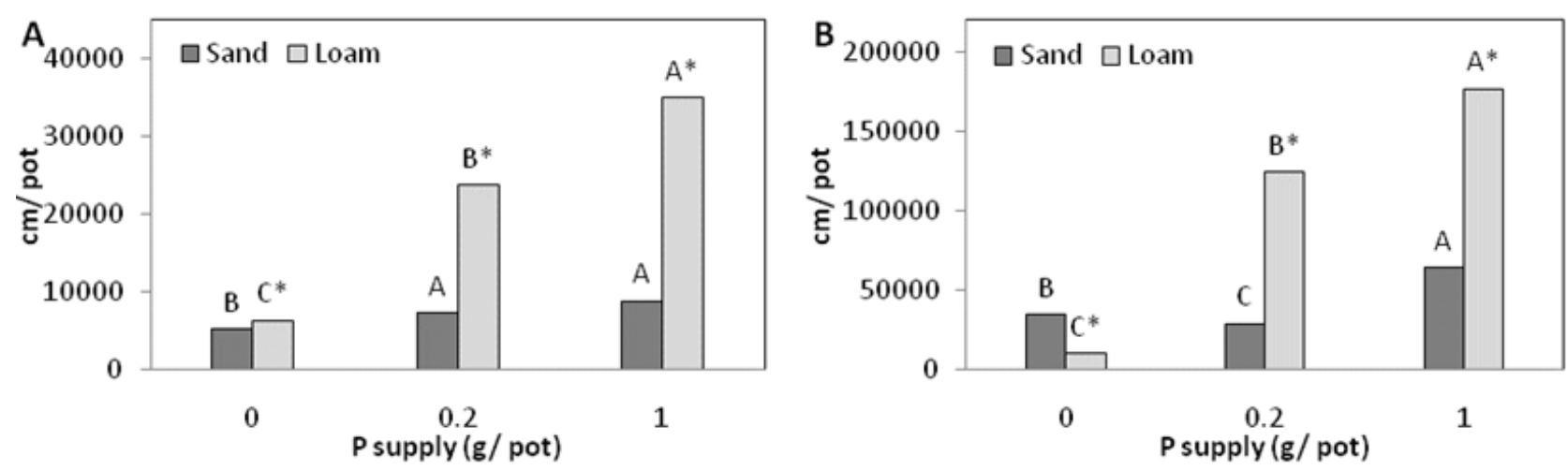

Figure 1. Effect of $\mathrm{P}$ supply on root length $\left(\mathrm{cm} \mathrm{pot}^{-1}\right)$ of safflower (A) and sunflower (B) in sandy soil and loamy soil. For a given species and a given soil type, means within each column followed by the same capital letter are not significantly different. * indicates significant difference for a given plant species and a given $\mathrm{P}$ level within soil types. $\mathrm{P}<0.05, \mathrm{n}=3$ 
Specific root density (cm root/ g root) decreased significantly with improving $\mathrm{P}$ supply in both soil types in safflower, and in sunflower when grown in loamy soil, while the opposite was found in sunflower grown in sandy soil (Table 4). Specific root density for each plant species were similar in different soil type. This trait was higher in safflower as compared to sunflower in sandy soil, while the opposite was recorded in loamy soil. Root radius was significantly reduced at low $\mathrm{P}$ supplies $\left(0\right.$ and $\left.0.2 \mathrm{~g} \mathrm{P} \mathrm{pot}^{-1}\right)$ as compared to high $\mathrm{P}$ supply (1.0g $\mathrm{P}$ pot $\left.^{-1}\right)$ in safflower grown in both soil types and in sunflower grown in loamy soil, while the values for sunflower grown in sandy soil were reduced but this reduction was statistically not significant (Table 4). Root radius of safflower was significantly less than that of sunflower at all respective $P$ supplies in both soil types, but this trait remained similar in each plant species and different soil type.

Root-shoot ratio (RSR)

Both species had higher root shoot ratios at low $\mathrm{P}$ supplies in both soil types (Figure 2). RSR was found significantly lower in safflower as compared to sunflower in both soil types. This trait didn’t change significantly for safflower in respective $\mathrm{P}$ levels among soil types. In sunflower, this parameter was similar at low $\mathrm{P}$ supply in both soil types, lower in sandy soil at intermediate $\mathrm{P}$ supply and the opposite was recorded at high P level.

Table 4. Effect of $P$ supply specific root density $(\mathrm{cm} / \mathrm{g}$ root) and root radius $(\mathrm{cm} x \mathbf{1 0 0 0})$ of safflower and sunflower. For a given species and a given soil type, means within each column followed by the same capital letter are not significantly different, means in the same soil type and the same $P$ level and different plant species followed by the same small letter are not significantly different, * indicates significant difference for a given plant species and a given $P$ level within soil types. $P<0.05, n=3$

\begin{tabular}{|c|c|c|c|c|}
\hline \multirow{2}{*}{$\begin{array}{l}\text { K supply } \\
\left(\mathrm{g} \mathrm{pot}^{-1}\right)\end{array}$} & \multicolumn{2}{|c|}{ Specific root density (cm/g root) } & \multicolumn{2}{|c|}{ Root radius $(\mathrm{cm})$} \\
\hline & Sandy & Loam & Sandy & Loam \\
\hline \multicolumn{5}{|l|}{ Safflower } \\
\hline 0 & $2500.1 \mathrm{~A}, \mathrm{a}$ & $2899.4 \mathrm{~A}, \mathrm{a}$ & 0.0115 B, b & $0.0111 \mathrm{~B}, \mathrm{~b}$ \\
\hline 0.2 & 2166.1 B, a & 2143.2 B, a & $0.0122 \mathrm{~B}, \mathrm{~b}$ & $0.0122 \mathrm{~B}, \mathrm{~b}$ \\
\hline \multicolumn{5}{|l|}{ Sunflower } \\
\hline 0 & 1498.7 B, b & 1619.3 A, b & $0.0146 \mathrm{~A}, \mathrm{a}$ & $0.0141 \mathrm{~B}, \mathrm{a}$ \\
\hline 0.2 & 1357.3 B, b & 1547.3 A, b & $0.0153 \mathrm{~A}, \mathrm{a}$ & $0.0144 \mathrm{~B}, \mathrm{a}$ \\
\hline 1.0 & $1605.2 \mathrm{~A}, \mathrm{~b}$ & $1373.5 \mathrm{~B}, \mathrm{~b}$ & $0.0143 \mathrm{~A}, \mathrm{a}$ & $0.0154 \mathrm{~A}, \mathrm{a}$ \\
\hline
\end{tabular}
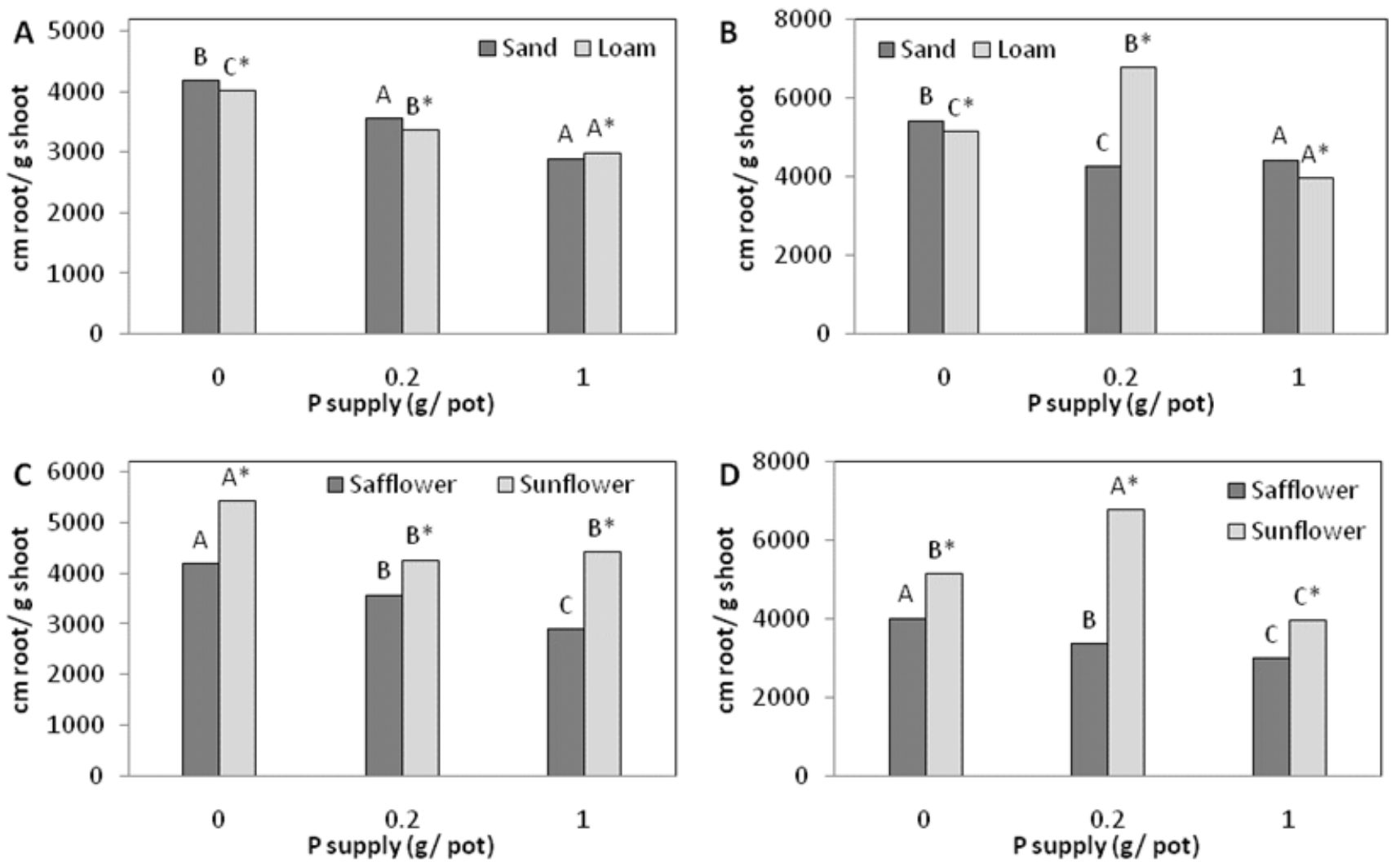

Figure 2. Effect of P supply on root-shoot ratio (cm root/ g shoot) pot ${ }^{-1}$ of safflower and sunflower in sandy soil and loamy soil. For a given species and a given soil type, means within each column followed by the same capital letter are not significantly different. * indicates significant difference between the two columns at each P supply (A and B) or a given plant species ( $C$ and $D$ ) at the same $P$ level. $P<0.05, n=3$ 


\section{Phosphorous influx}

Phosphorous influx ( $\rho m o l \mathrm{P} / \mathrm{cm}$ root/ second) increased significantly at high $\mathrm{P}$ supply in both species in both soil types as compared to low P supplies (Figure 3). This figure for safflower grown in sandy soil was found the highest in the intermediate P supply and was similar in both high and low P supplies. Both species showed similar $\mathrm{P}$ influx when grown in sandy soils at low P supply, while safflower was more efficient than sunflower in loamy soils. At intermediate $\mathrm{P}$ levels, safflower roots were more efficient in $\mathrm{P}$ uptake as compared to that of sunflower in both types of soil. At high P supplies safflower roots were inferior in $\mathrm{P}$ uptake as compared to that of sunflower roots in both soil types. Comparing each crop in different soil types, $\mathrm{P}$ influx was similar at each respective $\mathrm{P}$ level, except for safflower at high $\mathrm{P}$ supply, where the value was significantly less in sandy soil as compared to that grown in loamy soil.

\section{Shoot demand (SD)}

Shoot demand (SD) on the root is the $\mathrm{P}$ acquisition load imposed by shoot growth on each $\mathrm{cm}$ of the root and is calculated by dividing the shoot growth rate by the average root length, assuming that the roots of plants grow exponentially (Figure 4). Shoot demand on roots increased significantly with decreasing $\mathrm{P}$ supply in both species and

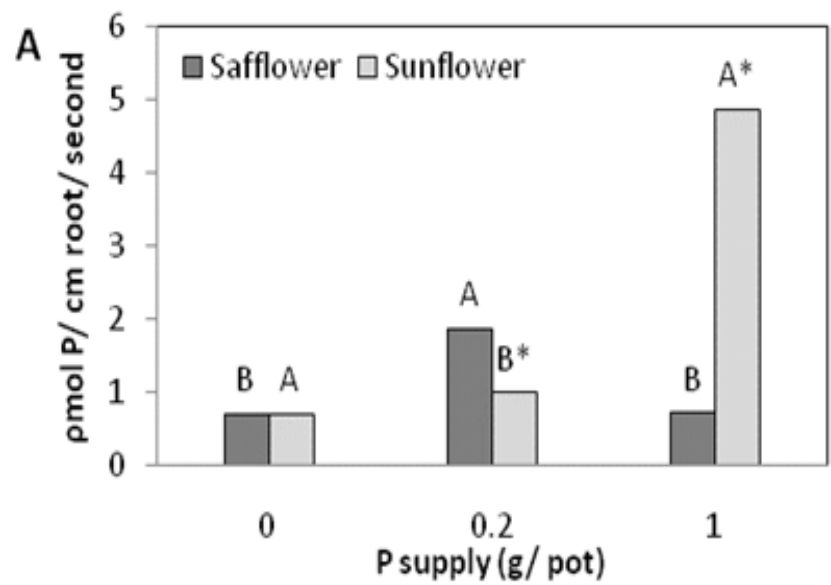

both soil types. It was higher in safflower than that of sunflower at each respective $\mathrm{P}$ supply for each soil type separately. It was higher in sandy soil as compared to loam soil at respective $\mathrm{P}$ supplies for each species separately.

\section{$P$ concentration in dry matter}

Phosphorous concentration (g P $100 \mathrm{~g}^{-1} \mathrm{DM}$ ) increased significantly in leaves, stems and shoots of both species with increasing $P$ supplies in both soils (Table 5). At 0 and $0.2 \mathrm{~g}$ added $\mathrm{P}$ supplies, safflower grown in both soil types contained significantly similar $\mathrm{P}$ concentration in their leaves, while at high $\mathrm{P}$ supplies safflower grown in loamy soil concentrated more $\mathrm{P}$ in their leaves as compared to those grown in sandy soil. Sunflower leaves concentrated more $\mathrm{P}$ in their leaves when they were grown in sandy soils as compared to that in loamy soils at very low $\mathrm{P}$ supply $\left(0 \mathrm{~g} \mathrm{P}\right.$ pot $\left.^{-1}\right)$ and high $\mathrm{P}$ supply (1 $\left.\mathrm{g} \mathrm{P}_{\mathrm{P}} \mathrm{pot}^{-1}\right)$ while the opposite was found at the intermediate $\mathrm{P}$ level $\left(0.2 \mathrm{~g} \mathrm{P}^{-1}\right)$. When grown in sandy soil both species concentrated similar values of leaves $\mathrm{P} \%$ at respective low P levels ( 0 and $0.2 \mathrm{~g}$ $\mathrm{P}$ pot $^{-1}$ ), while the same figure was significantly lower in safflower leaves as compared to sunflower at high $\mathrm{P}$ supply. In loamy soil, sunflower leaves contained significantly higher $\mathrm{P} \%$ than safflower at respective 0.2 and $1.0 \mathrm{~g} \mathrm{P}^{\mathrm{P}}{ }^{-1}$ while at 0 added $P$, the opposite was found.

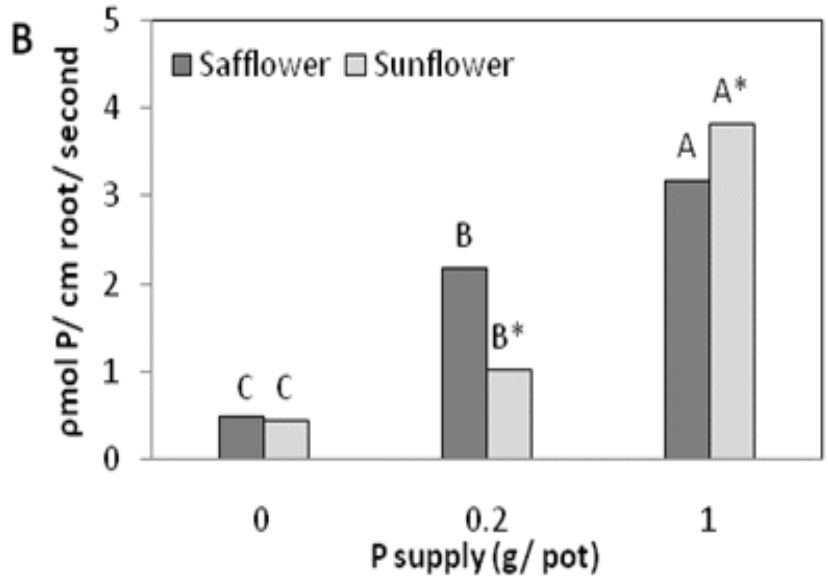

Figure 3. Effect of $\mathrm{P}$ supply on $\mathrm{P}$ influx ( $\mathrm{pmol} \mathrm{P} / \mathrm{cm}$ root/ second) for safflower and sunflower in sandy (A) and loamy (B) soil. For a given species and a given soil type, means within each column followed by the same capital letter are not significantly different. * indicates significant difference between columns at the same $\mathrm{P}$ level. $\mathrm{P}<0.05, \mathrm{n}=3$
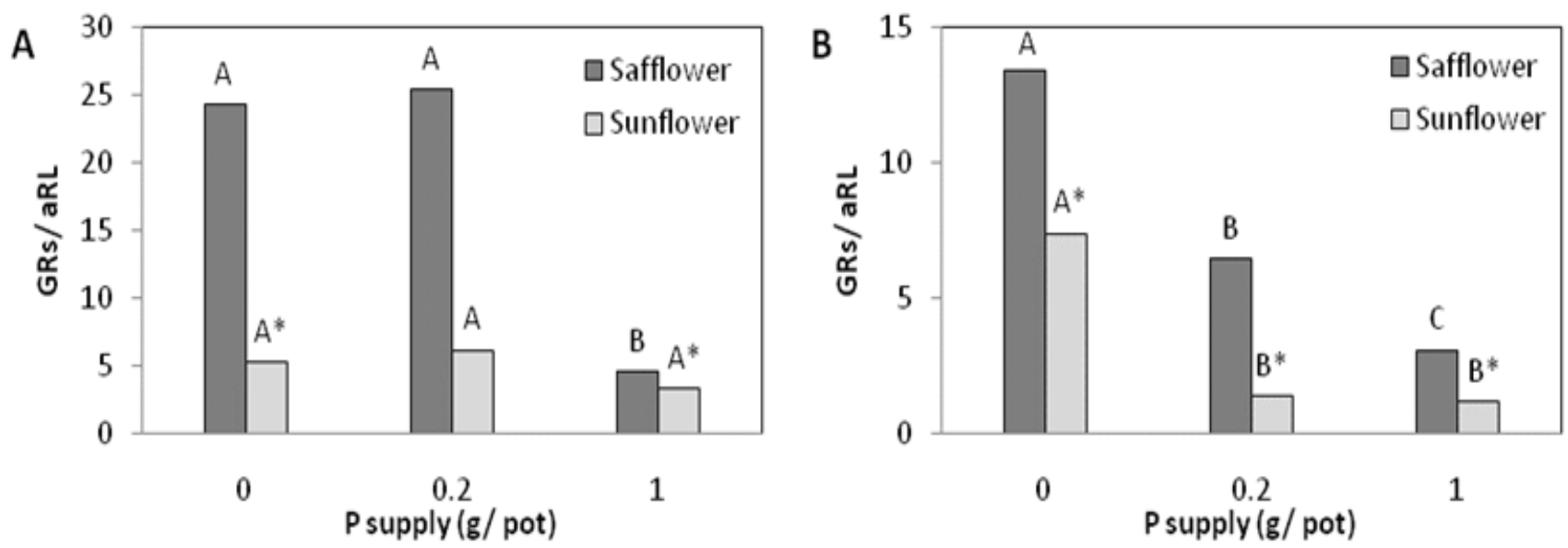

Figure 4. Effect of P supply on shoot demand; shoot growth rate (GRs)/average root length (aRL) ratio for safflower and sunflower in sandy (A) and loamy (B) soil. For a given species and a given soil type, means within each column followed by the same capital letter are not significantly different. * indicates significant difference between the two columns at the same $\mathrm{P}$ level. $\mathrm{P}<0.05, \mathrm{n}=3$ 
$\mathrm{P}$ concentrations in stems of both species were found lower than that of leaves at all respective $\mathrm{P}$ levels in both soil types. Both species contained significantly similar stem $\mathrm{P} \%$ in the same soil type and respective low $\mathrm{P}$ supplies ( 0 and $0.2 \mathrm{~g} \mathrm{P} \mathrm{pot}^{-1}$ ), while safflower concentrated less $\mathrm{P}$ at high $\mathrm{P}$ supply (1g $\mathrm{P}$ pot $\left.^{-1}\right)$ in respective soil type. When grown in sandy soil, safflower stems contained higher, similar, and lower $\mathrm{P} \%$ as compared to that grown in loamy soil when grown at $0.0,0.2$, and $1.0 \mathrm{~g} \mathrm{P} \mathrm{pot}^{-1}$ respective. The same figure concerning sunflower showed that sunflower stems contained similar P concentrations at respective $\mathrm{P}$ supplies within the two soil types.
Shoots of both crops contained similar P\% at respective 0 and $0.2 \mathrm{~g} \mathrm{P} \mathrm{pot}^{-1}$ in both soils, while safflower shoot $\mathrm{P} \%$ was significantly lower than that of sunflower in both soil types at high $\mathrm{P}$ supply. Comparing $\mathrm{P} \%$ in shoots of each plant species within soil type reveals that both species concentrated significant higher values when grown in sandy soils as compared with loamy soil at 0 added $\mathrm{P}$ supplies. At $0.2 \mathrm{~g} \mathrm{P}$ supply, $\mathrm{P} \%$ was similar in safflower among soil types, while that of sunflower was higher in loamy soil. At high $\mathrm{P}$ supply, shoots of safflower concentrated more $\mathrm{P}$ in loamy soil while the opposite was recorded for sunflower.

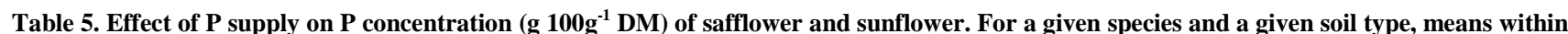
each column followed by the same capital letter are not significantly different, means in the same soil type and the same $P$ level and different plant species followed by the same small letter are not significantly different, * indicates significant difference for a given plant species and a given $P$ level within soil types. $P<0.05, n=3$

\begin{tabular}{|c|c|c|c|c|c|c|}
\hline \multirow{2}{*}{$\begin{array}{l}\text { K supply } \\
\left(\mathrm{g} \mathrm{pot}^{-1}\right)\end{array}$} & \multicolumn{2}{|c|}{ Leaves } & \multicolumn{2}{|c|}{ Stem } & \multicolumn{2}{|c|}{ Shoot Dry Weight } \\
\hline & Sandy & Loam & Sandy & Loam & Sandy & Loam \\
\hline \multicolumn{7}{|l|}{ Safflower } \\
\hline 0 & $0.289 \mathrm{~B}, \mathrm{a}$ & $0.207 \mathrm{C}, \mathrm{a}$ & $0.107 \mathrm{~B}, \mathrm{a} *$ & $0.068 \mathrm{~B}, \mathrm{a}$ & $0.207 \mathrm{~B}, \mathrm{a} *$ & $0.150 \mathrm{C}$, a \\
\hline 0.2 & 0.361 BA, a & 0.395 B, b & $0.172 \mathrm{~B}, \mathrm{a}$ & $0.128 \mathrm{~B}, \mathrm{a}$ & $0.287 \mathrm{~B}, \mathrm{a}$ & $0.283 \mathrm{~B}, \mathrm{a}$ \\
\hline \multicolumn{7}{|l|}{ Sunflower } \\
\hline 0 & $0.307 \mathrm{~B}, \mathrm{a} *$ & $0.153 \mathrm{C}, \mathrm{a}$ & 0.122 B. a & $0.107 \mathrm{~B}, \mathrm{a}$ & $0.227 \mathrm{~B}, \mathrm{a}$ * & 0.137 C, a \\
\hline 0.2 & $0.337 \mathrm{~B}, \mathrm{a} *$ & $0.432 \mathrm{~B}, \mathrm{a}$ & $0.143 \mathrm{~B}, \mathrm{a}$ & $0.151 \mathrm{~B}, \mathrm{a}$ & $0.257 \mathrm{~B}, \mathrm{a} *$ & $0.307 \mathrm{~B}, \mathrm{a}$ \\
\hline 1.0 & $0.917 \mathrm{~A}, \mathrm{a} *$ & $0.791 \mathrm{~A}, \mathrm{a}$ & $0.693 \mathrm{~A}, \mathrm{a}$ & $0.584 \mathrm{~A}, \mathrm{a}$ & $0.840 \mathrm{~A}, \mathrm{a} *$ & $0.690 \mathrm{~A}, \mathrm{a}$ \\
\hline
\end{tabular}

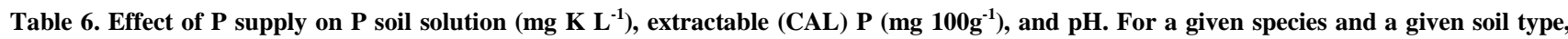
means within each column followed by the same capital letter are not significantly different, means in the same soil type and the same $P$ level and different plant species followed by the same small letter are not significantly different, * indicates significant difference for a given plant species and a given $P$ level within soil types. $P<0.05, \mathrm{n}=3$

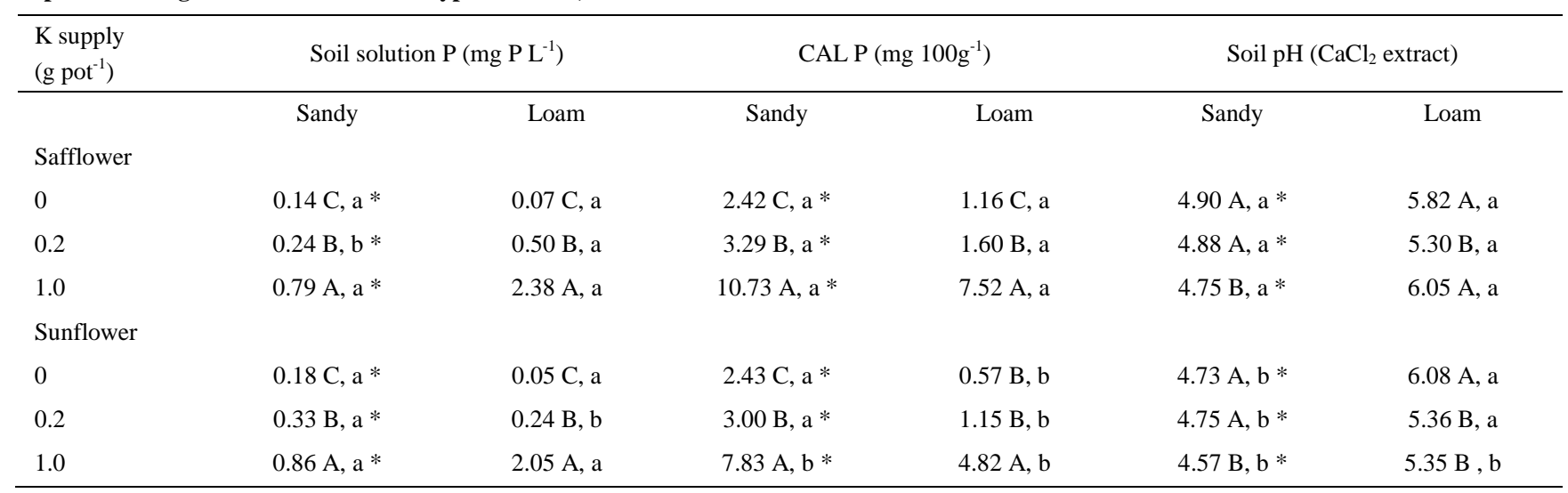
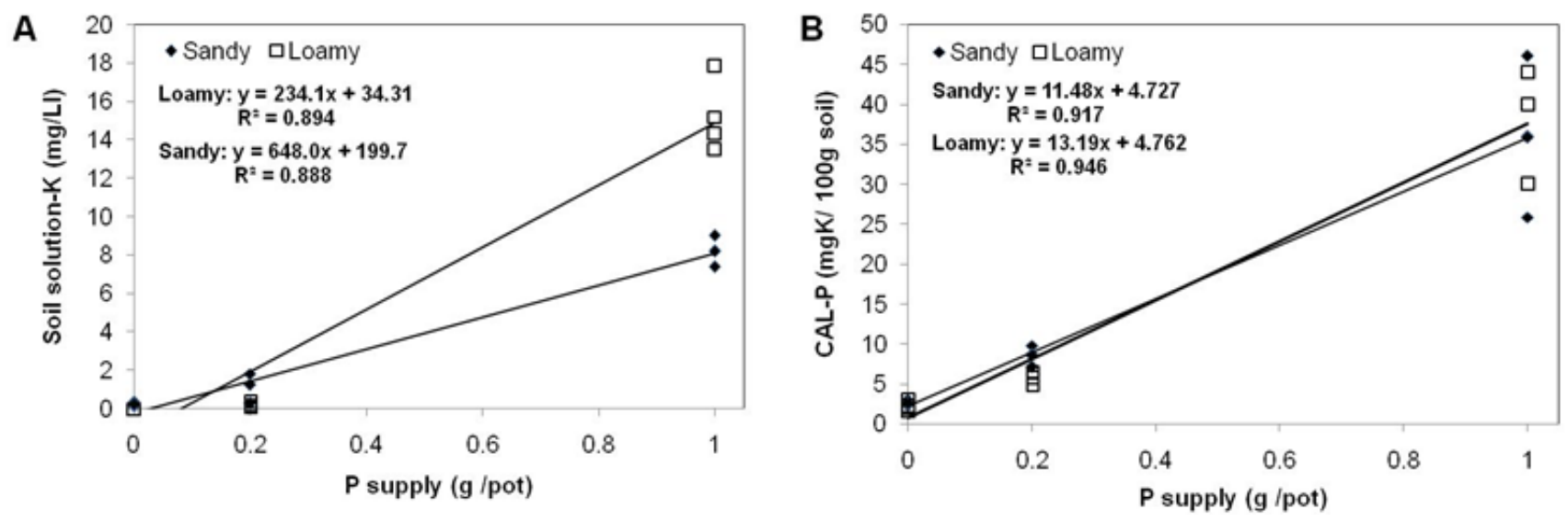

Figure 5. Effect of P supply (g/ pot) on soil solution P (mg P/ L soil solution) (A) and CAL-P (mg P/ 100g soil) (B) in unplanted pots loamy and sandy soil 

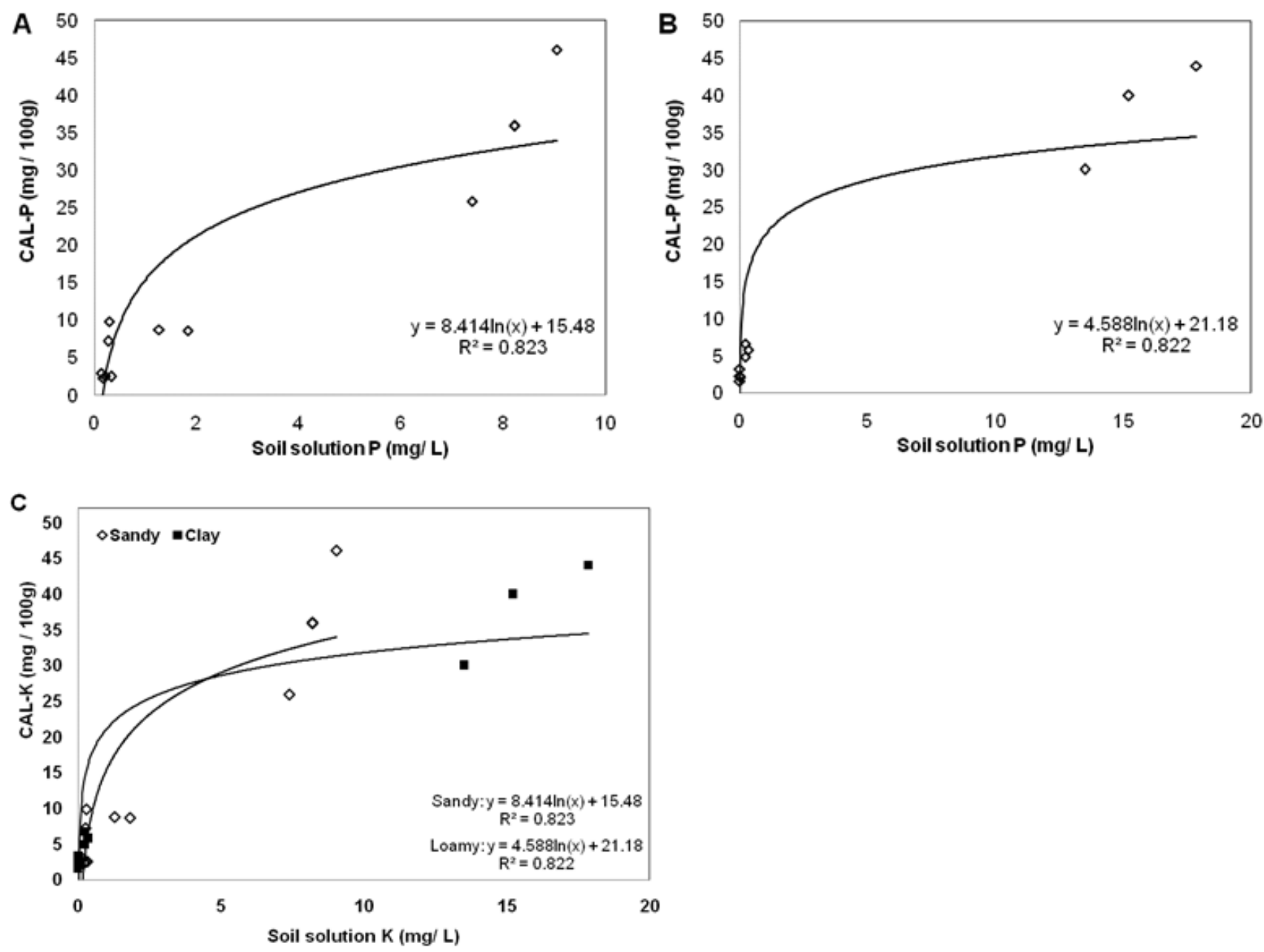

Figure 6. Relationship between extractable (CAL) P and soil solution in unplanted pots of loamy soil (A) and sandy soil (B), and both soils (C) with increasing $\mathrm{P}$ levels, $\mathrm{n}=4$

\subsection{Soil Parameters}

\section{Available (soil solution) P, extractable (Calcium Acetate Lactate (CAL)) $\mathbf{P}$, and $\mathbf{p H}$}

Soil solution around roots of both plants increased significantly with increasing $\mathrm{P}$ supply in both plant species and both soil types (Table 6). Soil solution was found similar in both species in the same soil type at very low and very high $\mathrm{P}$ supplies, while it was lower in safflower at intermediate P supply in sandy soil and the opposite was found in loamy soil. In safflower, soil solution was significantly higher in sandy soil as compared to loamy soil at all respective $\mathrm{P}$ supplies, and similar response was recorded for sunflower except for high P supply where the opposite was observed. Calcium acetate lactate (CAL) extractable P increased significantly with increasing external $\mathrm{P}$ supply in both soils for both crops (Table 6). CAL-P was significantly higher in sandy soil in all respective $\mathrm{P}$ supplies for both plant species. The values were significantly lower for sunflower in loamy soil at all respective $\mathrm{P}$ supplies and in sandy soil at high $\mathrm{P}$ fertilization level, while values were similar for both species at 0 and $0.2 \mathrm{~g} \mathrm{pot}^{-1}$ in sandy soil. Soil pH in sandy soils for both species decreased in the highest $\mathrm{P}$ supply only (Table 6). $\mathrm{pH}$ in loamy soil for safflower was significantly reduced in the intermediate P supply and was reduced significantly in both 0.2 and $1.0 \mathrm{~g}$ pot ${ }^{-1}$ for sunflower.
In the unplanted pots of both types of soil, the soil solution contained increasing amounts of $\mathrm{P}$ as a function of increasing external $\mathrm{P}$ supply. The solution obtained from loamy soils had significantly higher than that obtained from sandy soil at high added P levels (Figure 5, material and methods section). Both soils had significantly similar extractable $\mathrm{P}$ at all respective $\mathrm{P}$ levels (Figure 5, Figure 6, material and methods section). Buffer power is normally calculated as the ratio of soil exchangeable $\mathrm{P}$ (mol cm$~^{-3}$ soil) and the soil solution $\mathrm{P}$ concentration (mol cm${ }^{-3}$ soil solution). Figure 6 demonstrates the relation between both sources of $\mathrm{P}$ and the relation for both soil types fit the Langmuir isotherm showing the relationship between the adsorbed and equilibrium phosphorous concentration (quantity/intensity).

\section{Discussion}

\subsection{Growth and Morphology}

Biomass is an important plant trait in growth analysis and the key parameter in many allometric relationships $[57,58]$. Repeated measurements of biomass are the basis for the calculations of net primary production and growth rates [59], and thus a basis for quantifying physiological responses of plants to environmental conditions and their developmental processes. Thus the production of shoot 
dry matter is generally considered a good indicator of ultimate economic yield [60]. Therefore cultivars differences for shoot dry matter production indicated that this trait can be used as reliable parameter for screening efficient cultivars $[13,61]$.

Phosphorus is needed most by young, fast growing tissues, and performs a number of functions related to growth, development, photosynthesis and use of carbohydrates; hence, $\mathrm{P}$ deficient soils produce poor plant growth and yield. P deficiency reduces leaf expansion, auxiliary bud growth and shoot canopy, therefore, reduces the plant's photosynthetic surface area and carbohydrate utilization [1]. Since cell and leaf expansion are more retarded than chloroplast and chlorophyll formation [62], low P supply increases the soluble protein and chlorophyll content per unit leaf area, resulting in small and darker green leaves [63]. It is stated that the decrease in leaf number and size is one of the earliest and most reliable responses of $\mathrm{P}$ deficient plants [64]. Leaf expansion occurs due to cell multiplication and elongation of the newly formed cells in plants and turgor pressure is a crucial factor for cell expansion [65]. There were instances, where P-deficiency decreased the hydraulic conductivity of water in the roots $[66,67]$, and reduced the water potential of the plant, possibly by lowering the activity of the water channel proteins, aquaporins [67]. It is also possible that P-deficiency induced the closure of stomata [66], improving the water potential of these organs temporarily. The decrease in hydraulic conductivity of the root and stomatal conductance of the leaf, result in a severe reduction of leaf expansion under P-deficiency [67]. In addition to the afore mentioned effects on vegetative growth, low-P supply also limits the formation of reproductive organs, results in premature leaf senescence, delayed flower initiation [15], decreased number of flowers [14] and restricted seed formation $[15,16]$, and all contribute to yield reductions under $\mathrm{P}$ limited conditions.

In agreement with our results concerning dry weight (Table 1) and fresh weight (Table 2), $\mathrm{P}$ nutrition was reported to have a positive influence on dry matter production in sunflower $[12,68]$ and safflower $[13,15]$. The reduction of leaf biomass of both species in both soils under study (Table 1, Table 2) was particularly strong (more than stems) and was more pronounced in loam soil (relative DM production). Indeed, in plants suffering from $\mathrm{P}$ deficiency, reduction in leaf area [69] and leaf number [64] is the most striking effect. Although the contents of chlorophyll per unit leaf area are often increased under $\mathrm{P}$ deficiency [63], the photosynthetic rate per unit area is typically reduced [68], suggesting that both effects (reduction of leaf area and reduction of net photosynthesis per unit of leaf area) may contribute to the final reduction of biomass production. Unlike other reports, sunflower was more sensitive to $\mathrm{P}$ deficiency than safflower in terms of relative dry matter accumulation (Table 2) in loam soil under the very low and intermediate P supply and in sandy soil at intermediate $\mathrm{P}$ supply [15,70] and the same response was reflected in the relative fresh and dry weights of leaves, stems, and roots (fresh weight). The contribution of the stem in reducing dry matter as affected by sub-optimal external $P$ was less than that of leaves and may be caused by the reduction of stem diameter and the height of the plants [16]. The effect of $\mathrm{P}$ supply on increasing the number of branches per plant in safflower was reported [15].

\section{Shoot and root growth rate}

Differences between plant species were also found in the shoot growth rates (Table 3); hence, a plant with a low shoot growth rate could be considered more efficient than that with high growth rate under suboptimal P supply [28]. The high rates of root growth under low $\mathrm{P}$ supply was reported in safflower in both soil types but was not reported in sunflower in this investigation and may be because low-P supplied plants diverted more of their photosynthates toward roots as less $\mathrm{P}$ was utilized in shoot growth. Certainly there were much higher levels of starch and sucrose in fibrous roots than leaves in low-P plants, indicating a considerable transport of photosynthates to roots had occurred. Also C-export belowground as a fraction of total C-export from leaves to roots is increased in plants under suboptimal P [71]. Accordingly, safflower could be indicated more efficient than sunflower in both soil types in reducing their growth rate of shoots under suboptimal $\mathrm{P}$ supplies, and in the same time by enhancing the growth rate of their roots in both soils under low $\mathrm{P}$ supply (Table 3).

\subsection{P Uptake Efficiency}

Nutrient uptake efficiency depends on factors related to plant parameters and other factors related to soil parameters. Factors related to plant parameters were evaluated in this investigation include, root length [43,72], root diameter $[73,74,75]$, root-shoot ratio $[72,76]$, nutrient influx [76], shoot growth rate per unit root or shoot demand on roots [77,78]. Soil parameters include soil solution P [39], extractable P [79], and pH [80].

\section{Root biomass, root length and root-shoot ratio}

Phosphorus acquisition efficiency is defined partly in terms of total uptake per plant and is related to root size, root morphology and $\mathrm{P}$ mobility in soil making $\mathrm{P}$ acquisition by the plant very dependent on soil exploration in time and space [33, 34, 81]. Nutrient uptake by plants starts with contact between plant roots and the nutrients in soil due to large root system [43]. Safflower produced less root size and root length than sunflower interpreted as absolute root fresh weight (Table 1, Figure 1) because safflower is small plant as compared to sunflower. In the other hand, the relative root size and also relative root length (value at a particular $\mathrm{P}$ supply related to the value at the highest $\mathrm{P}$ supply) of safflower were much higher than that of sunflower when both species were grown at low P supply in either sandy or loamy soil. This indicate that safflower can increase the relative root size (weight and length) under low $\mathrm{P}$ supply which enable the plant to overcome the low $\mathrm{P}$ availability by increasing its root size to explore more soil volume. This agree with a previous findings stated that the total root-length production of Beta vulgaris in field plots at harvest was $120 \mathrm{~km} \mathrm{~m}^{2}$ in high-P plots, and $200 \mathrm{~km} \mathrm{~m}^{2}$ in low-P plots [72]. In the same line with our findings for safflower in both soil types concerning relative root size (Table 1), relative root length, specific root density, root radius (Figure 1) and also rootshoot ratio (Figure 2), researchers found plants grown under low P supply can modify their root system (length, 
fineness, density of their root for greater absorbing surface) to exploit larger volume of soil and/or increase the root length-shoot weight ratio [76]. The ratio between root length and shoot weight is a basic parameter of nutrient acquisition by plants [82]. This increase in root-shoot ratio (RSR) under low-P supply have been regarded as a kind of adaptive response in roots to low external levels of $\mathrm{P}$ [71]. Because RSR is affected by the nutritional status of plants, shortage of $\mathrm{P}$ supply was found to increase the ratio of root length per weight of plants [82]. An increase in RSR is due to the more reduction of shoot growth than root growth in $\mathrm{P}$ deficient plants $[83,84]$ and can be attributed to higher export rates of photosynthates to the roots and use of photoassimilates in the roots and increasing root surface area for P-absorption enabling the stressed plants to acquire more $\mathrm{P}$ from the surrounding environment [85]. This adaptive response under low $\mathrm{P}$ supply was less pronounced in sunflower than safflower in terms of specific root density and root radius when they were grown in loamy soil and was also not applicable for sunflower when they were grown in sandy soil (Table 4). The root-shoot ratio (cm root/ gm shoot) in safflower was less than that of sunflower at all respective $\mathrm{P}$ supplies in both soil types (Figure 2). P-deficiency induce more dry matter partitioning in favor of heterotrophic tissue, thus reducing growth of photosynthetic tissue [86] and therefore allocate more biomass to roots when $\mathrm{P}$ is limiting for their growth [82], a mechanism was used by safflower and sunflower in both soil types in this investigation. In contrary with our findings, many Lupinus species show little change in biomass partitioning to roots as dependent on P supply [78], despite that some of them were indicated as P-efficient.

The root system is responsible for feeding the plant, and the amount of $\mathrm{P}$ absorbed depends on the size of the root surface developed to explore larger volumes of soil to feed the shoot biomass by a better $\mathrm{P}$ acquisition ability of the plants [87]. Although, the contact with P (root interception) occurs through the growth of roots to the places where nutrients are available [88], but the amount of nutrients accessible in this way is difficult to quantify. This contact also occurs through the transport of nutrients from the soil to the root surface. As root systems can be quantified in terms of length, surface area, or weight of the roots related to the size of the shoot, it can be related to volume of soil, or to soil surface area. In the cases where plants were found to respond to $\mathrm{P}$ supply with a change in specific root length (SRL) -termed as specific root density in this investigation-, their SRL increased with decreasing $\mathrm{P}$ supply $[73,75]$ which was clearly reported in safflower grown in both soil types and in sunflower grown in loamy soil only. In the same line with our findings (Figure 2), the increase in SRL is associated with a decrease in root diameter [73], especially for the apical regions of the root system [74]. However, a decrease in root diameter is by no means a universal response to a low $\mathrm{P}$ supply [75]. Another parameter that was not measured in this research and is associated with P uptake efficiency is root hairs [89].

\section{Root P Influx}

The second component of nutrient uptake efficiency related to roots after the root size and morphology is the root physiological activity [5,90]. Differing uptake kinetics in superior and inferior species, can be a result of different nutrient uptake rates per unit root and time [91]. Phosphorus uptake kinetics parameters include maximum net influx per centimeter of root $\left(\mathrm{I}_{\max }\right)$, Michaelis- constant $\left(\mathrm{K}_{\mathrm{m}}\right)$ and minimum soil solution concentration $\left(\mathrm{C}_{\mathrm{Lmin}}\right)$ [12]. Under conditions in which the rate-determining step in $\mathrm{P}$ uptake is related to the root, $\mathrm{P}$ uptake will increase if root length per unit plant weight and $\mathrm{I}_{\max }$ increase, and $\mathrm{K}_{\mathrm{m}}$ and $\mathrm{C}_{\min }$ decrease [92]. These parameters vary with $\mathrm{P}$ concentration in the soil solution. In contrary with our findings (Figure 3), other researchers reported an increase in $I_{\max }$ values under $P$ deficient supply $[93,94]$. In our research, the $\mathrm{P}$ influx in the roots of both species was reduced under low $\mathrm{P}$ supply which indicate that both species don't use this mechanism to enhance $\mathrm{P}$ uptake under $\mathrm{P}$ deficiency. The $\mathrm{P}$ influx of safflower was higher than sunflower at low P supply but was the opposite at high $\mathrm{P}$ supply. Other researchers documented that $\mathrm{K}_{\mathrm{m}}$ and $\mathrm{C}_{\min }$ values were not affected by P supply [94].

The influx can be used to express plant's nutrient demand on the roots. This sink property can be described as follows [33]: In = X RGR * (W/RL). The sink intensity depends on the nutrient concentration in the plant (X), the relative growth rate (RGR), and the ratio of total plant weight (W) to root length (RL). All these parameters change with plant species [95,96], variety [82,97], and are more pronounced at developmental stage [96]. The ability of plants to adapt their morphological and physiological root characteristics to variable nutrient availability is genetically determined [98,99]. Previous reports found that, the influx of $\mathrm{P}$ per unit root length greatly enhanced by root hairs [89], a trait was not investigated in this research.

The assessment of the kinetic parameters $\left(\mathrm{I}_{\max }, \mathrm{K}_{\mathrm{m}}\right.$ and $\mathrm{C}_{\text {min }}$ ) by characterizing the uptake mechanism of a genotype is complicated by at least three factors [30]: (i) the plasticity of the system in response to the $\mathrm{P}$ status of the plant [89]; (ii) the differences in $\mathrm{P}$ uptake along roots [100]; and (iii) the dependence of $\mathrm{P}$ uptake on plant growth rate [101]. Thus there is general agreement that the efficiency of the uptake system is of minor importance for $\mathrm{P}$ acquisition from soils because transport of $\mathrm{P}$ to the root surface rather than the uptake is the limiting step [34]. Therefore it is less likely that selection for efficient $\mathrm{P}$ uptake kinetics will contribute to more efficient $\mathrm{P}$ acquisition from low-P soils, and accordingly, choosing this trait is not applicable in selecting safflower and sunflower for P uptake efficiency.

\section{Shoot demand for $P$ on roots}

As mentioned above, roots have mainly to meet the nutrient demand exerted by shoot growth $[77,101]$. Hence, the shoot growth rate together with the required $\mathrm{P}$ concentration in the shoot is a measure of the demand, the shoot is putting on each root segment. Therefore, shoot demand (SD) on the root is interpreted as the $\mathrm{P}$ acquisition load imposed by shoot growth on each $\mathrm{cm}$ of root and is calculated by dividing the shoot growth rate by the average root length (RL), assuming that the roots of the plants grow exponentially: $\left.(\mathrm{GRs} / \mathrm{RL})=\left(\left(\mathrm{SW}_{2}-\mathrm{SW}_{1}\right) / \mathrm{t}_{2}-\mathrm{t}_{1}\right)\right)$ $\mathrm{X} \ln \left(\left(\mathrm{RL}_{2} / \mathrm{RL}_{1}\right) / \mathrm{RL}_{2}-\mathrm{RL}_{1}\right)$. Table 3 shows the shoot growth rate per unit of safflower and sunflower root length calculated during the first and second harvest when grown in sandy and loamy soils as affected by increasing $\mathrm{P}$ supplies. The higher SD ratio of safflower as compared 
to sunflower at all respective $\mathrm{P}$ supplies and more pronouncedly at low P supply (Figure 4), was attributed to the lower values of root length/ shoot dry matter ratio in safflower as compared to sunflower (Figure 2) not to a faster shoot growth rate of the former as compared to the later (Table 3). Since the shoot $\mathrm{P}$ concentration in safflower was less than that of sunflower (Table 5), and $P$ root influx was found similar in both species (Figure 3), the higher $\mathrm{P}$ demand per unit root length of safflower as compared to sunflower could be attributed mostly to the lower values of root length-shoot dry matter ratio in safflower as compared to sunflower (Figure 2)

\section{$P$ concentration and accumulation}

Phosphorus efficient crops, adapted to low P-supplying soils, are often characterized by low $\mathrm{P}$ requirements [83]. A number of crop species can grow normally with low tissue $\mathrm{P}$ concentrations due to efficient use of $\mathrm{P}$ among the major biochemical fractions (soluble-P, lipid-P, and residue- $\mathrm{P}$ ) and was found to be more tolerant to low $\mathrm{P}$ conditions than that, which exhibited high $\mathrm{P}$ concentrations in the tissues [102]. The plant that maintains relatively low tissue concentration of $\mathrm{P}$ due to the efficient incorporation of the external $\mathrm{P}$ into residue-P [103], and because the vacuole acts as a $\mathrm{P}$ reservoir to maintain a constant cytoplasmic P concentration [104] are more tolerant to low $\mathrm{P}$ conditions.

Both species under investigation had the same internal $\mathrm{P}$ concentration in their plant parts and shoot at low and intermediate $\mathrm{P}$ supplies (Table 5) but this figure was less in safflower tissues as compared to sunflower when the crops were grown in high added $\mathrm{P}$ soil which could be explained by the dilution effect because of the large biomass production of sunflower plants [105,106]. Plant parts of both species had more P concentration when they were grown in sandy soils as those were cultivated in loamy soil because of the higher availability of $\mathrm{P}$ in sandy soil having low fixing ability of $\mathrm{P}$ as compared to loamy soil. As the nutritional status of the plant can be characterized by the $\mathrm{P}$ concentration in the dry matter, optimal plant growth requires $\mathrm{P}$ in the range of 0.3 to $0.5 \%$ of dry matter during the vegetative growth stage [12] is in agreement of our findings where the $\mathrm{P}$ deficient plants had $\mathrm{P}$ concentration in their plant parts and shoots lower these limits (Table 5). The productive efficiency of $\mathrm{P}$ for grain or seed is higher at early growth stages than at later stages because $\mathrm{P}$ is needed for tillering or branching. If sufficient $\mathrm{P}$ is absorbed at early growth stages, it will be redistributed to other growing organs [1,12,15,16,104].

Phosphorus supply significantly affected the $\mathrm{P}$-concentration [P] (Table 5) and the accumulated $\mathrm{P}$ in tissues of the tested species was also reported in Brassica spp. [85], and for both species studied earlier [12,13]. More root growth [74] and more distribution of $\mathrm{P}$ to the roots as root are good sink for P under P-stress [107] are among reasons that reduce $\mathrm{P}$ concentration and accumulation in vegetative parts and make plants retain more $\mathrm{P}$ in their roots than shoots [85] in plants under P-starvation conditions.

\subsection{Soil Parameters}

Genotypic differences in P efficiency can be examined in field as well as in pot experiments with soil or with nutrient solution $[108,109]$. However, contradictory results may be obtained when a plant species or genotypes are evaluated using these three experimental systems due to different growth conditions. Results from pot trials with soil and especially from field trials can be not easily repeatable due to soil heterogeneity and complexity, and even using the same soil in pot experiments, the results are often not repeatable because the availability of nutrient can change during the soil storage. However, pot trials compared to field trials have the advantage that uniform growth conditions can be set regarding fertilization and soil homogeneity and also, that weather effects can be largely controlled. On the other hand, although nutrient solution experiments can be easily repeated, this can cover only part of the factors, which can be responsible for genotypic differences in nutrient efficiency by plants growing in soil. For instance, the root growth conditions and $\mathrm{P}$ uptake are substantially different between nutrient solution experiments and pot soil trials. Additionally, the relevance of different plant and non plant factors (soil) in $\mathrm{P}$ uptake would be different according to the experimental methodology used. To illustrate these differences between different growth conditions, it was reported that in early growth stages under field conditions, groundnut was not limited by low $\mathrm{P}$ soil $(1.9 \mu \mathrm{M} \mathrm{P})$, whereas maize only yielded $15-35 \%$ of its maximum yield [39]. In contrast with these findings, using the same plant material under flowing solution culture, the same researchers reported that maize was more $\mathrm{P}$ efficient since it was able to produce up to $90 \%$ of its maximum yield at only $1 \mu \mathrm{M} \mathrm{P}$ concentration in the nutrient solution, whereas groundnut was inefficient, producing only $20 \%$ of its maximum yield at this P concentration [110].

Plant species and even varieties of same species differ in their ability to grow in soil low in nutrients [12,111]. Efficient species and cultivars are those can utilize mobile, available, fixed nutrients in soil and can exploit more soil in order to maintain required rate of nutrient uptake by roots [111]. As discussed earlier, plant properties affecting uptake of nutrients from soil were kinetics of ion absorption by roots, the size of root system and morphological root properties [36]. Other properties are related to soil in which the supply of mineral nutrients to plants is the result of interactions between the nutrient availability in soil and the ability of plants to absorb this nutrient. Both soil and plant properties are therefore, important for the nutrition of plants.

Soils, characterized by having loamy texture may contains more than $20 \%$ iron or aluminium oxides in their clay particles, which "fix" or sorb rapidly large quantities of added phosphorus, transforming them into slowly soluble iron and aluminium phosphates that are not available to the plants [112]. Moreover, soils with a high $\mathrm{P}$ sorption capacity are able to absorb up to $5600 \mathrm{~kg} \mathrm{ha}^{-1} \mathrm{P}$ until they are able to provide satisfactory crop growth [113]. On the other hand, diffusion of phosphorus "flux" through the soil to the plant's roots, is -in many soils- the mechanism governing 90 to $98 \%$ of the $\mathrm{P}$ supply to the roots [114].

Mass flow and diffusion are the two mechanisms for nutrient movement from soil to root [115]. Diffusion is of fundamental importance for the availability of nutrients to plants growing in soil [82], because at low as well as 
optimum soil nutrient concentrations, diffusion supplies much higher ion quantities from soil to roots than mass flow. Because a concentration gradient is required for diffusion to occur, the plant root takes up nutrients, lowers the nutrient concentration on its outside, and thus creates a gradient unless mass flow counteracts the process. Therefore the decrease of the nutrient concentration at the root surface is determined by the uptake properties of roots. Both species under study, in both soils had similar soil solution $\mathrm{P}$ at respective low and high $\mathrm{P}$ levels (Table 6) which indicate that both species have similar ability to deplete available $\mathrm{P}$ at respective $\mathrm{P}$ supplies. This was also reflected by the similar values of $\mathrm{P}$ influx among species in both soils at low P supplies (Figure 3). The extension of the depleted zone and the degree of depletion depends also on the nutrient mobility in the soil. Hence, ion diffusion from soil to root is basically the result of interactions between plant and soil. The plant efficient species is that can maintain higher nutrient influx by increasing diffusion towards roots due to its capability to use/release more soil nutrients than other species which resulted in the increase of concentration gradient [116].

The $\mathrm{P}$ supply represented as soil solution used in this investigation tested in pots before planting was 6.9, 19.6, and $256 \mu \mathrm{mol} \mathrm{P} \mathrm{L}{ }^{-1}$ in sandy soil and $0.2,7.3,419 \mu \mathrm{mol} \mathrm{P}$ $\mathrm{L}^{-1}$ in loamy soils after adding $\mathrm{P}$ levels $(0,0.2$, and $1 \mathrm{~g} \mathrm{P}$ pot $^{-1}$ ). The normal concentration of $\mathrm{P}$ in soil solution in the field, reported previously $[117,118]$ was in the order of 0.32 - $19.37 \mu \mathrm{mol} \mathrm{P} \mathrm{L}^{-1}$, and this concentration can be depleted rapidly by growing roots in soil. As solution $\mathrm{P}$ falls below its equilibrium concentration, it is replenished by labile $\mathrm{P}$ desorbed from loamy mineral surfaces adjacent to the roots [119]. Consequently, $\mathrm{P}$ moves from the adsorbed forms into solution and along a concentration gradient to the depletion zone of the root where the $\mathrm{P}$ concentration is low. However, in P-limited soils, the quantity of labile $\mathrm{P}$ may be insufficient to maintain $\mathrm{P}$ solution concentration against depletion by plant root. Thus this specific soil condition influences the movement of $\mathrm{P}$ toward the root surface because gradient is the driving force of diffusive $\mathrm{P}$ flux. On the other hand, $\mathrm{P}$ inflow depends on the concentration at the root surface, for that $\mathrm{P}$ depletion may imply severe restriction of $\mathrm{P}$ inflow into plants. It has been reported that the $\mathrm{P}$ concentration in soil solution (external $\mathrm{P}$ requirement) necessary to achieve maximum growth differs widely among crops. Using flowing solution cultures, a 25-fold difference in external $\mathrm{P}$ requirements among eight plant species and a 200-fold difference for other 18 species was reported [120]. In the field using adsorption isotherms, the external $\mathrm{P}$ requirements of a range of crops and vegetables were variable [119]. The external $P$ requirements for several crop species varies in the range of 2 to $22 \mu \mathrm{mol} \mathrm{L}{ }^{-1}$ [117]. Hence, at a low $\mathrm{P}$ concentration in soil solution, $\mathrm{P}$ efficient plants may be either those with a low external $\mathrm{P}$ requirement or those which are able to achieve their external requirement by developing of morphological and/or physiological root mechanisms.

Beside the relationship between $\mathrm{P}$ concentration and growth of plants, extractable $\mathrm{P}$ in the soil can be a measure of its availability. Ions not readily released from the soil matrix when the ambient solution concentration is low could be of minor importance to plants. But there is some evidence that phosphate fractions not detected by conventional soil test methods may play a role in supplying $\mathrm{P}$ to plants [79]. In utilizing these sources, plant roots function as more than sinks for diffusing ions. Both species depleted similar amounts of extractable $\mathrm{P}$ in sandy soil at both low and intermediate $\mathrm{P}$ supplies indicating a similar efficiency in solubilizing $\mathrm{P}$ from unavailable $\mathrm{P}$ pool in the soil, but sunflower was superior as compared to safflower at high P supply in sandy soil. The efficiency in accessing more $\mathrm{P}$ from unavailable $\mathrm{P}$ pool in loamy soil was more for sunflower as compared to safflower at all respective $\mathrm{P}$ supplies as the extracted $\mathrm{P}$ in soil hosting sunflower was lower than that for safflower at all respective $P$ levels (Table 6 ).

The $\mathrm{pH}$ of the soil has a major influence on $\mathrm{P}$ solubility. Table 6 shows the $\mathrm{pH}$ of the soil as affected by plant species in increasing $\mathrm{P}$ supply in both soils. As an efficiency to slubilize scarce $\mathrm{P}$ under very low $\mathrm{P}$ supply, the $\mathrm{pH}$ of soil should be reduced, which was not applicable for both species and both soil types under investigation, where $\mathrm{pH}$ in both soils for both crops was significantly higher in deficient $\mathrm{P}$ supply under study. The $\mathrm{pH}$ was reduced by safflower at the highest $\mathrm{P}$ supply in sandy soil and at intermediate P supply in loamy soil. The $\mathrm{pH}$ value of soil hosting sunflower was reduced in sandy soil at the highest $\mathrm{P}$ supply and at both intermediate and high $\mathrm{P}$ levels in loamy soil. Sunflower reduced the $\mathrm{pH}$ of the sandy soil as compared to that of safflower but $\mathrm{pH}$ of the soil in loamy soil was not affected among plant species at low and intermediate $\mathrm{P}$ supplies. In contrary with our findings, it was reported that, the application of fertilizer did not produce any effect on the $\mathrm{pH}$ value [80]. It is well known that, the roots of many, if not all, plant species are able to exude substances which increase the solubility of soil P [121]. Exudates include protons that decrease the soil pH [122], reducing and chelating agents [123], organic acids [124] and phosphatase enzymes [125]. As the reduction of $\mathrm{pH}$ in the rhizosphere depends on the root activities to solubilize more $\mathrm{P}$, the reduction of $\mathrm{pH}$ in soil at higher $\mathrm{P}$ supplies in both species and both soil was because the larger root systems of both species at higher $\mathrm{P}$ supplies (Table 1), therefore higher solubilizing efficiency, however they have less shoot demand of $\mathrm{P}$ on roots (Figure 4) under high P supplies in both soils.

\section{Conclusion}

New crops need to be developed, to acquire soil P more efficiently by focusing on species which represent uptake efficiency traits. Plant species vary in their $\mathrm{P}$ use efficiency at different $\mathrm{P}$ supplies and different soils by using different strategies related to uptake efficiency that could be used in selecting or breeding programs. P uptake efficiency depends on those factors related to plant parameters and those related to soil parameters. Efficient crop in terms of plant parameters increases root size, root length, specific root density, root-shoot ratio, nutrient influx and reduces root diameter, shoot growth rate and shoot demand on roots. The ability of the crop species to increase $\mathrm{P}$ solubility in the rhizosphere $(\mathrm{P}$ intensity and capacity) and depleting more soil solution and extractable $\mathrm{P}$, along with acidifying the rhizosphere are considered as 
mechanisms of $\mathrm{P}$ uptake efficiency in terms of soil parameters.

Under low P supplies (0, 0.2 external P), both species had similar agronomic $\mathrm{P}$ efficiency in both soils. Safflower had less absolute root length, higher relative root length, higher specific root density, thinner root diameter, less root shoot ratio in both soils. Safflower was superior as compared to sunflower in terms of P influx in both soil soils (except at $0 \mathrm{P}$ supply in sandy soil where both species were similar). Safflower had higher shoot demand on root because of the less root length and higher shoot growth rate, although it had higher $\mathrm{K}$ influx. At very low $\mathrm{P}$ supply, both species depleted the same soil solution $\mathrm{P}$ in both soils and CAL-P in sandy soil, while sunflower depleted more CAL-P in loamy soil. Both species under study share both efficiency and inefficiency traits concerning both plant and soil parameters in different soils. Therefore using different measures of uptake efficiency parameters to differentiate plant species and genotypes to superior and inferior could be in some cases misleading.

\section{Acknowledgments}

Financial support for this study was obtained from the German Academic Exchange Service (DAAD), through a Re-invitation Programme for Former Scholarship Holders (A/12/08202 and 50068612), the Palestinian funding program for research and training "ZAMALAH", and the Dutch EP-NUFFIC through NICHE-233 project. Technical support by Mrs. S. Koch in department of plant nutrition and yield physiology, George-August University, Goettingen, Germany for her generous help in plant and soil samples analyses is gratefully acknowledged.

\section{Competing Interests}

None declared.

\section{Abbreviations}

P- Phosphorus, NUE- Nutrient use efficiency, CALCalcium acetate lactate, DM- Dry matter, RL- root length, RFW- root fresh weight, $\mathrm{r}_{0}$ - root radius, RLv- specific root density, GRs- shoot growth rate, GRr- root growth rate, In- influx, SW- shoot weight, t- time, SD- shoot demand, RSR- root shoot ratio.

\section{References}

[1] Marschner, H, Mineral Nutrition of Higher Plants, 2nd ed., Academic Press, London, 1995

[2] Vance, C.P., Uhde-Stone, C., and Allan, D.L, "Phosphorus acquisition and use: critical adaptations by plants securing a nonrenewable resource", New Phytologist, 157. 423-457. 2003.

[3] Winfried, E. and Blum, H, "Soil and Land Resources for Agricultural Production: General Trends and Future Scenarios-A Worldwide Perspective", International Soil and Water Conservation Research, 1 (3). 1-14. 2013.

[4] Ashley, K., Cordell, D., Mavinic, D, "A brief history of phosphorus: From the philosopher's stone to nutrient recovery and reuse", Chemosphere 84. 737-746. 2011.
[5] Lambers, H., Shane, M.W, Cramer M.D, Pearse S.J. and Veneklaas E.J, "Root Structure and Functioning for Efficient Acquisition of Phosphorus: Matching Morphological and Physiological Traits", Annals of Botany, 98. 693-713. 2006.

[6] Nadira, U.A., Ahmed, I.M., Zhu, B., Zeng, J., Cai, S., Wu, F. and Zhang, G, "Identification of Tibetan wild barley genotypes with high tolerance to low phosphorus stress", Journal of Food, Agriculture \& Environment, 12 (2). 408-214. 2014.

[7] Richardson, S.J., Peltzer, D.A., Allen, R.B., McGlone, M.S. and Parfitt, R.L, "Rapid development of phosphorus limitation in temperate rainforest along the Franz Josef soil chronosequence", Oecologia, 139. 267-276. 2004.

[8] Pachauri, R.K. and Meyer, L.A, (eds.), IPCC, Climate Change: Synthesis Report. Contribution of Working Groups I, II and III to the Fifth Assessment Report of the Intergovernmental Panel on Climate Change, IPCC, Geneva, Switzerland, 2014.

[9] Johnson, A.H., Frizano, J., Vann, D.R., and Johnson, R.A.H, "Biogeochemical implications of labile phosphorus in forest soils determined by the Hedley fractionation procedure", Oecologia, 135. 487-499. 2003

[10] Roy, R.N., Finck, A., Blair, G.J., Tandon, H.L.S, "Plant nutrition for food security, a guide for integrated nutrient management", FAO, Rom-Italy, 2006.

[11] Chardon, W., Withers, P, "Introduction to papers from the UECOST Action 832, Quantifying the agricultural contribution to eutrophication", Journal of Plant Nutrition and Soil Science, 166. 401. 2003.

[12] Abbadi, J. and Gerendás, J, "Phosphorous use efficiency of Safflower as compared to Sunflower", Journal of Plant Nutrition, 38 (7). 1121-1142. 2015.

[13] Abbadi, J, "Phosphorous use efficiency of safflower and sunflower grown in different soils", World Journal of Agricultural Research, 5 (4), 212-220. 2017.

[14] Abbadi, J, "Importance of nutrient supply (N, P, K) for yield formation and nutrient use efficiency of safflower (Carthamus tinctorius L.) compared to sunflower (Helianthus annuus L.) including an assessment to grow safflower under north German conditions", Grauer Publisher, Beuren Stuttgart, Germany, 2007.

[15] Abbadi, J. and Gerendás, J, "Effects of phosphorous supply on growth and yield of safflower as compared to sunflower", Journal of Plant Nutrition, 34 (12). 1769-1787. 2011.

[16] Abbadi, J. and Gerendás, J, "Phosphorous use efficiency of Safflower and Sunflower studied in nutrient solutions", Journal of Agricultural Science and Technology A, 2. 1260-1280. 2012.

[17] Watson, C.A., Atkinson, D., Gosling, P., Jackson, L.R. and Rays, F.W, "Managing soil fertility in organic farming systems", Soil Use and Management, 18. 239-247. 2002.

[18] Berry, P., Stockdale, E., Sylvester-Bradley, R., Philipps, L., Smith, K., Lord, E., Watson, C. and Fortune, S, "N, P and K budgets for crop rotations on nine organic farms in the UK", Soil Use and Management, 19. 112-118. 2003.

[19] Maranguit, D., Guillaume, T. and Kuzyakov, Y, "Land-use change affects phosphorus fractions in highly weathered tropical soils", Catena, 149. 385-393. 2017.

[20] Singh, B. and Ryan, J, "Managing Fertilizers to Enhance Soil Health", International Fertilizer Industry Association (IFA). Paris. France. 2015

[21] Gourley, C.J.P., Allan, D.L. and Russelle, M.P, "Plant nutrient efficiency: A comparison of definitions and suggested improvement", Plant and Soil, 158. 29-37. 1994.

[22] Shahid, S.A. and Al-Shankiti, A, "Sustainable food production in marginal lands-Case of GDLA member countries", International Soil and Water Conservation Research, 1 (1). 24-38. 2013.

[23] Spiertz, H, "Challenges for Crop Production Research in Improving Land Use, Productivity and Sustainability", Sustainability, 5. 1632-1644. 2013.

[24] Wang, Y.P., Law, R.M., and Pak, B, "A global model of carbon, nitrogen and phosphorus cycles for the terrestrial biosphere", Biogeosciences, 7. 2261-2282. 2010.

[25] Goll, D.S., Brovkin, V., Parida, B.R., Reick, C.H., Kattge, J., Reich, P.B., Van Bodegom, P.M., and Niinemets, Ü, "Nutrient limitation reduces land carbon uptake in simulations with a model of combined carbon, nitrogen and phosphorus cycling", Biogeosciences, 9. 3547-3569. 2012.

[26] Yang, X., Thornton, P.E., Ricciuto, D.M., and Post, W.M, "The role of phosphorus dynamics in tropical forests - A modeling study using CLM-CNP", Biogeosciences, 11. 1667-1681. 2014. 
[27] Reed, S.C., Yang, X., and Thornton, P.E, "Incorporating phosphorus cycling into global modeling efforts: A worthwhile, tractable endeavor", New Phytologist, 208. 324-329. 2015.

[28] Dessougi, H. Claassen, N, and Steingrobe, B. "Potassium efficiency mechanisms of wheat, barley and sugar beet grown on a $\mathrm{K}$ fixing soil under controlled conditions", Journal of Plant Nutrition and Soil Science, 165, 732-737. 2002.

[29] Dechassa, N., Schenk, M.K., Claassen, N., and Steingrobe, B, "Phosphorus efficiency of cabbage (Brassica oleraceae L. var. capitata), carrot (Daucus carota L.), and potato (Solanum tuberosum L.) ", Plant and Soil, 250. 215-224. 2003.

[30] Sattelmacher, B., Horst, W.J. Becker, H.C, "Factors that contribute to genetic variation for nutrient efficiency of crops", Journal of Plant Nutrition and Soil Science, 157. 215-224. 1994.

[31] Abbadi, J., Gerendás, J. and Sattelmacher, B, "Effects of nitrogen supply on growth, yield and yield components of safflower and sunflower", Plant and Soil, 360. 167-180. 2008.

[32] Abbadi, J. and Gerendás, J, "Nitrogen Use Efficiency of Safflower as compared to Sunflower", Journal of Plant Nutrition, 32(6). 929-945. 2009

[33] Nye, PA. and Tinker. P.B, "Solute Movement in the soil-root system", Studies in Ecology, Blackwell Scientific Publisher, Oxford. 1977.

[34] Barber, S.A, Soil Nutrient Bioavailability. John Wiley \& Sons, New York. 1984

[35] Jungk, A, "Root hairs and the acquisition of plant nutrients from soil", Journal of Plant Nutrition and Soil Science 164. 121-129. 2001.

[36] Jungk, A. and Claassen, N, "Ion diffusion in the soil-root system", Advances in Agronomy, 61. 53-110. 1997.

[37] Syers, J.K., Johnston, A.E. and Curtin. D, "Efficiency of soil and fertilizer phosphorus use", FAO Fertilizer and Plant Nutrition Bulletin, 18. Rome, Italy. 2008.

[38] Johnston, A.E, "Principles of crop nutrition for sustainable food production", Proceedings, 459., International Fertilizer Society., York, UK., 2001.

[39] Bhadoria, P.S., Singh, S. and Claassen, N, "Phosphorus efficiency of wheat, maize and groundnut grown in low phosphorus supplying soil", In W.J. Horst et al. eds. Plant Nutrition- Food security and sustainability of Agro-ecosystems. Dordrecht, Kluwer Academic Publishers. 530-531. 2001.

[40] Schenk, M.K, "Nutrient efficiency of vegetable crops", Acta Horticulturae, 700. 21-34. 2006.

[41] Johnston, A.E.J., and Syers, J.K, "A new approach to assessing phosphorus use efficiency in agriculture", Better Crops Plant Food, 93. 14-16. 2009.

[42] Rausch, C. and Bucher, M, "Molecular mechanisms of phosphate transport in plants", Planta, 216. 23-37. 2002

[43] Fitter, A, "Characteristics and functions of root systems", in Plant Roots: The Hidden Half. Waisel, Y., Eshel, A., and Kafkafi, U. (eds.), $2^{\text {nd }}$ ed., Dekker, New York. 1-20. 1996.

[44] Koevoets IT, Venema JH, Elzenga JTM and Testerink, C, "Roots Withstanding their Environment: Exploiting Root System Architecture Responses to Abiotic Stress to Improve Crop Tolerance", Frontiers in Plant Science, 7. 1335. 2016.

[45] Trona, S., Bodnerb, G., Laioc, F., Ridolfic, L. and Leitnera, D, "Can diversity in root architecture explain plant water use efficiency? A modeling study", Ecological Modeling, 312 200-210. 2015

[46] Zaehle, S. and Friend, A.D, "Carbon and nitrogen cycle dynamics in the O-CN land surface model: 1. Model description, site-scale evaluation, and sensitivity to parameter estimates", Global Biogeochemical Cycles, 24. 1-13. 2010.

[47] Oliveira, E.M.M., Ruiz, H.A., Hugo, V., Ferreira P.A., Costa F.O. and Ameida I.C.C, "Nutrient supply by mass flow and diffusion to maize plants in response to soil aggregate size and water potential", Revista Brasileira De Ciência Do Solo, 34. 317-328. 2010.

[48] Giehl, R.F.H. and von Wirén, N, "Root Nutrient Foraging", Plant Physiology, 166. 509-517. 2014.

[49] Tinker, P.B, Nye, P.H, Solute Movement in the Rhizosphere, Blackwell Scientific, Oxford. 2000.

[50] Rashmi, I., Biswas, A.K., Shinogi, K.C., Kala, S., Karthika, K.S., Prabha, S.P. and Sao, Y, "Phosphorus Movement and Vertical Distribution in Four Soil Orders of India: Column Leaching Experiment", International Journal of Current Microbiology and Applied Sciences, 6(4). 1919-1930. 2017.
[51] Ticconi, C.A., Lucero, R.D., Sakhonwasee, S., Adamson, A.W., Creff, A., Nussaume, L., Desnos, T. and Abel, S, "ER-resident proteins PDR2 and LPR1 mediate the developmental response of root meristems to phosphate availability", Proceedings of the National Academy of Sciences, USA 106: 14174-14179. 2009.

[52] Gericke, S., Kurmies, B, "Die kolorimetrische Phosphorsäure bestimmung mit Ammonium, Vanadat, Molybdat und ihre Anwendung in der Pflanzenanalyse", Zeitschrift für Pflanzenernährung, Düngung, Bodenkunde, 59. 235-247. 1952.

[53] Adams F, "Soil solution", in Carson EW (ed) The plant root and its environment. University of Virginia, Charlottesville, 441-481. 1974.

[54] Schüller, H, "Die CAL-Methode, eine neue Methode zur Bestimmung des pflanzenverfügbaren phosphates in Böden" [The CAL method, a new method for the determination of plantavailable phosphate in soils]. Journal of Plant Nutrition and Soil Science, 123. 48-63.1969.

[55] Tennant, D, "A test of a modified line intersect method of estimating root length", Journal of Ecology, 63. 995-1001. 1975.

[56] Williams, R.F, "The effect of phosphorus supply on the rates of intake of phosphorus and nitrogen upon certain aspects of phosphorus metabolism in gramineous plants", Australian Journal of Scientific Research (B) Biological Sciences, 11. 333-361. 1948.

[57] West, G.B., Brown, J.H., and Enquist, B.J, "A general model for the structure and allometry of plant vascular systems", Nature 400. 664-667. 1999.

[58] Niklas, K.J. and Enquist, B.J, "On the vegetative biomass partitioning of seed plant leaves, stems, and roots", American Naturalist, 159. 482-497. 2002.

[59] Cornelissen, J.H.C., Lavorel, S., Garnier, E., D1'az, S., Buchmann, N., Gurvich, D.E., Reich, P.B., ter Steege, H., Morgan, H.D., van der Heijden, M.G.A., Pausas, J.G. and Poorter. H, "A handbook of protocols for standardised and easy measurement of plant functional traits worldwide", Australian Journal of Botany, 51. 335-380. 2003.

[60] Gill, M.A., Mansoor, S., Aziz, T., Rahmatullah and Akhtar, M.S "Differential growth response and phosphorus utilization efficiency of rice genotypes", Pakistan Journal of Agricultural Sciences, 39.83-87. 2002.

[61] Gill, M.A., Sabir, M., Ashraf, S., Rahmatullah, and Aziz, T, "Effect of P-stress on growth, phosphorus uptake and utilization efficiency of different cotton cultivars", Pakistan Journal of Agricultural Sciences, 42. 42-47. 2005.

[62] Hecht-Bucholz, C, "Über die Dunkelfarbung des Blattgruns bei Phosphormangel", Zeischrift für Pflanzenernährung und Bodenkunde, 118. 12-22. 1967.

[63] Rao, I.M. and Terry. N, "Leaf phosphate status, photosynthesis, and carbon partitioning in sugar beet. IV. Changes with time following increased supply of phosphate to low-phosphate plants", Plant Physiology, 107, 1313-1321. 1995.

[64] Lynch, J., Läuchli, A. and Epstein, E, "Vegetative growth of the common bean in response to phosphorous nutrition", Crop Science, 31. 380-387. 1991.

[65] Munns, R., Passioura, J.B., Guo, J., Chazen, O. and Cramer, G.R, "Water relations and leaf expansion: importance of time scale", Journal of Experimental Botany, 51. 1495-1504. 2000.

[66] Radin, J.W, "Responses of transpiration and hydraulic conductance to root temperature in nitrogen-and phosphorusde®cient cotton seedlings", Plant Physiology, 92, 855-857. 1990.

[67] Clarkson, D.T., Carvajal, M., Henzler, T., Waterhouse, R.N., Smyth, A.J., Cooke, D.T. and Steudle, E, "Root hydraulic conductance: diurnal aquaporin expression and the effects of nutrient stress", Journal of Experimental Botany 51, 61-70. 2000.

[68] Rodríguez, D., Zubillaga, M. M. Ploschuk, E.L. Keltjens, W.G. Goudriaan, J. and Lavado, R.S, "Leaf area expression and assimilate production in sunflower (Helianthus annuus L.) growing under low phosphorus conditions", Plant and Soil, 202. 133-147. 1998.

[69] Freeden, A.L., Rao, I.M. and Terry, N, "Influence of phosphorus nutrition on growth and carbon partitioning in Glycine max", Plant Physiology, 89. 225-230. 1989.

[70] Colomb, B., Debaeke, P. Jouany, C. and Nolot. J.M, "Phosphorus management in low input stockless cropping systems: Crop and soil responses to contrasting $P$ regimes in a 36-year experiment in southern France", European Journal of Agronomy, 26. 154-165. 2007. 
[71] Persanov, V.M., Andreeva, T.F, "Effect of duration of phosphorus starvation on outflow and utilization of assimilates in connection with plant growth and productivity", Fiziol Rast, 17. 1175-1181. 1970.

[72] Steingrobe, B., "Root renewal of sugar beet as a mechanism of P uptake efficiency. Journal of Plant Nutrition and Soil Science", 164. 533-539. 2001.

[73] Powell, C.L, "Mycorrhizal status of rushes and sedges in New Zealand", PhD thesis, University of Otago. Otago, New Zealand. 1974.

[74] Mollier A. and Pellerin S, "Maize root system growth and development as influenced by phosphorus deficiency", Journal of Experimental Botany, 50. 487-497. 1999.

[75] Schroeder, M.S., Janos, D.P, "Plant growth, phosphorus nutrition, and root morphological responses to arbuscular mycorrhizas, phosphorus fertilization, and intraspecific density", Mycorrhiza, 15. 203-216. 2005.

[76] Ciereszko, I., Janonis, A., Kociakowska, M, "Growth and metabolism of cucumber in phosphate-deficient conditions. Journal of Plant Nutrition", 25. 1115-1127. 2002.

[77] Claassen, N. and Jungk, A, "Bedeutung von Kaliumaufnahmerate, Würzelwachstum und Würzelhaaren für das Kaliumaneignungsvermtigen verschiedener Pflanzenarten", Zeitschrift für. Pflanzenernaehrung und Bodenkunde, 147,276-289. 1984.

[78] Pearse, S.J., Veneklaas, E.J., Cawthray, G., Bolland, M.D.A. and Lambers, $\mathrm{H}$, "Triticum aestivum shows a greater biomass response to a supply of aluminium phosphate than Lupinus albus, despite releasing fewer carboxylates into the rhizosphere", New Phytologist, 169. 515-524. 2006.

[79] Trehan, S.P, and Sharma, R.C. "Differences in phosphorus use efficiency in potato genotypes", Advances in Horticultural Science, 19 (1). 13-20. 2005.

[80] Castañeda Ortiz. N, "Phosphorus efficiency of Arachis pintoi genotypes and possible mechanisms for tolerance to low soil $\mathrm{P}$ supply". Doctoral Dissertation Submitted for the degree of Doctor of Agricultural Science of the Faculty of Agricultural Science Georg-August-University of Göttingen. 2006.

[81] Marschner, H. "Mechanisms of adaptation of plants to acid soils", Plant and Soil, 134, 1-20. 1991.

[82] Trehan, S.P. and Sharma, R.C, "Root-shoot ratio as an indicator of zinc uptake efficiency of different potato cultivars", Communications in Soil Science and Plant Analysis, 34. 919-32. 2003.

[83] Rao, I.M. and Terry, N. "Leaf phosphate status, photosynthesis, and carbon partitioning in sugar beet. IV. Changes with time following increased supply of phosphate to low-phosphate plants", Plant Physiology, 107, 1313-1321. 1995.

[84] Marschner, H., Kirkby, E.A. and Cakmak, I, "Effect of mineral nutritional status on shoot-root partitioning of photoassimilates and cycling of mineral nutrients", Journal of Experimental Botany, 47. 1255-1263. 1996

[85] Akhtar, M.S, Oki. Y. and Adachi, T, "Genetic Diversity in Brassica Cultivars under Deficiently Buffered P-Stress Environment: I. Biomass Accumulation, P-Concentration, PUptake, and Related Growth Parameters", Journal of American Science, 3(2). 55-63. 2007.

[86] Nielsen, K.L., Eshel, A. and Lynch, J.P, "The effect of phosphorus availability on the carbon economy of contrasting common bean (Phaseolus vulgaris L.) genotypes", Journal of Experimental Botany, 52. 329-339. 2001.

[87] Trolove, S.N., Hedley, M.J. Kirk, G.J.D. Bolan, N.S. and Loganathan, P, "Progress in selected areas of rhizosphere research on P acquisition", Australian Journal of Soil Research, 41 (3). 471-499. 2003.

[88] Oliver, S. and Barber, S.A, "An evaluation of the mechanisms governing the supply Of $\mathrm{Ca}, \mathrm{Mg}, \mathrm{K}$ and Na to soybeen roots", Soil Science Society of America, Proceedings, 30. 82-86. 1966.

[89] Jungk, A. and Claassen, N, "Availability in soil and acquisition by plants as the basis for potassium and phosphorus supply to plants", Zeitschrift für Pflanzenernährung und Bodenke, 152. 151-158. 1989.

[90] Kraimat, M. and Bissati, S, "Characterization of genotypic variability associated to the phosphorus bioavailability in peanut (Arachis hypogaea L.)", Annals of Agricultural Science, 62. 45-49. 2017.
[91] Steingrobe, B. and Claassen, N. "Potassium dynamics in the rhizosphere and K efficiency of crops", Journal of Plant Nutrition and Soil Science, 163. 101-106. 2000.

[92] Nielsen, N.E. "Is the efficiency of nutrient uptake genetically controlled?, in: J.L. Harley, Russel, R.S. (eds.). The Soil-Root Interface. New York: Academic Press, pp 429. 1979.

[93] Buhse, J, "Wirkung der Wurzelraumtemperatur auf das Phosphataneinungsvermögen von Pflanzen und die Phosphatverfügbarkeit im Boden", Ph.D. Thesis. University of Göttingen, Germany. 1992.

[94] Fontes, P.C.R., Barber, S.A. and Wilcox, G.E, "Prediction of phosphorus uptake by 2 tomato cultivars growing under insufficient and sufficient phosphorus soil-conditions using a mechanistic mathematical-model", Plant and Soil 94, 87-97. 1986.

[95] Trehan, S.P. and Claassen, N, "External K requirement of young plants of potato, sugar beet and wheat in flowing solution culture resulting from different internal requirements and uptake efficiency", Potato Research, 41.229-37. 1998.

[96] Trehan, S.P. and Sharma, R.C, "Phosphorus and zinc uptake efficiency of potato (Solanum tuberosum) in comparison to wheat (Triticum aestivum), maize (Zea mays) and sunflower (Helianthus annuus). Indian Journal of Agricultural Science, 70. 840-45. 2000.

[97] Trehan, S.P. and Sharma, R.C, "Potassium uptake efficiency of young plants of three potato cultivars as related to root and shoot parameters", Communications in Soil Science and Plant Analysis, 33. 1813-24. 2002.

[98] Horst, W.J., Abdou, M. and Wiesler. F, "Genotypic differences in phosphorus efficiency of wheat", Plant and Soil, 156, 293-296. 1993.

[99] Fransen, B., Blijjenberg, J. and de Kroon, H, "Root morphological and physiological plasticity of perennial grass species and the exploitation of spatial and temporal heterogeneous nutrient patches", Plant and Soil, 211. 179-189. 1999.

[100] Henriksen, G.H., Raja Raman, D. Walker, L.P. and Spanswick, R.M, "Measurement of net fluxes of ammonium and nitrate at the surface of barley roots using ion-selective microelectrodes. II. Patterns of uptake along the root axis and evaluation of the microelectrode flux estimation technique", Plant Physiology, 99 (2). 734-747. 1992.

[101] Engels, C, "Differences between maize and wheat in growthrelated nutrient demand and uptake of potassium and phosphorus at suboptimal root-zone temperatures", Plant and Soil, 150 (1). 129-138. 1993.

[102] Hart, A.L. and Jessop. D.J, "Phosphorus fractions in trifoliate leaves of white clover and lotus at various levels of phosphorus supply", New Zealand Journal of Agricultural Research, 26 (3). 357-361. 1983.

[103] Adu-Gyamfi, J.J., Fujita, K., and Ogata, S, "Phosphorus fractions in relation to growth in pigeon pea at various levels of P supply", Soil Science and Plant Nutrition, 36. 531-543. 1990.

[104] Rao, I.M, "The role of phosphorus in photosynthesis", in Pessarakli, M. (ed,). Handbook of Photosynthesis. New York: Marcel Dekker, pp 173-194. 1996.

[105] Bélanger, G., Claessens, A., Ziadi, N. "Grain N and P relationships in maize", Field Crops Research, 126. 1-7. 2012.

[106] Zhang, H.Y., Wu, H.H., Yu, Q., Wang, Z.W. and Wei, C,Z., et al "Sampling date, leaf age and root size: implications for the study of plant C:N:P stoichiometry, Plos One, 8. 60360. 2013.

[107] Mengel, K., and Kirkby, E.A, Principle of Plant Nutrition, Kluver academic pub., London. 2001.

[108] Graham, R.D, "Breeding for nutritional characteristics in cereals", Advances in Plant Nutrition, 1. 57-102. 1984.

[109] Gerloff, G.C., "Intact-plant screening for tolerance to nutrientdeficiency stress", Plant Soil, 99. 3-16. 1987.

[110] Bhadoria, P.S., El Dessougi, H., Liebersbach, H., and Claassen, N, "Phosphorus uptake kinetics, size of root system and growth of maize and groundnut in solution culture", Plant and Soil, 262. 327-336. 2004.

[111] Trehan, S.P., Singh, B.P, "Nutrient efficiency of different crop species and potato varieties - in retrospect and prospect", Potato Journal, 40 (1). 1-21. 2013.

[112] Sanchez, P.A., Palm C.A. and Buol. S.W, "Fertility capability soil classification: a tool to help assess soil quality in the tropics", Geoderma, 114 (3-4). 157-185. 2003.

[113] Sanchez, P.A. and Uehara, G, "Management considerations for acid soils with high phosphorus fixation capacity", in Khasawneh, 
F.E. Sample, E.C. Kamprath E.J. (eds.), The Role of Phosphorus in Agriculture. Madison, WI: ASA CSSA, SSSA, pp 471-514. 1980.

[114] Barber, S.A, "Soil-plant interactions in the phosphorus nutrition of plants", in Khasawneh, E. Sample, E.C. Kamprath E.J. (eds.), The Role of Phosphorus in Agriculture. Madison, WI: American Society of Agronomy, 591-616. 1980.

[115] Barber, S.A, "A diffusion and mass-flow concept of soil nutrient availability", Soil Science, 93. 39-49, 1962

[116] Trehan, S.P, "Mechanism of high nitrogen efficiency in potato cultivars", Advances in Horticultural Science, 23(3). 179-84. 2009.

[117] Kamprath, E.J. and Watson, M.E, "Conventional soil and tissue tests for assessing the phosphorus status of soils", in Khasawneh, F.E. Sample, E.C. Kamprath E.J. (eds.), The Role of Phosphorus in Agriculture, Madison, WI: ASA, CSSA, SSSA, pp 433-469. 1980.

[118] Wild, A, "Plant nutrients in soil: phosphate", in Wild A. (ed.), Russell's Soil Conditions and Plant Growth, $11^{\text {th }}$ ed. Essex, England: Longman Scientific and Technical, pp 695-742. 1988.

[119] Fox, R.L, "External phosphorus requirements of crops", in Dowdy, R.H. Ryan, J.A. Volk, V.V. Baker D.E. (Eds.), Chemistry in the Soil
Environment, Spec. Publ. No. 40, American Society of Agronomy and Soil Society of America, Madison, 1981, pp. 223-239.

[120] Asher, C.J, in Rechcigl, M. Jr, (ed.), CRC Handbook Series in Nutrition and Food, 3. Boca Rotan, FL: CRC Press, 575. 1978.

[121] Darrah, P.R, "The rhizosphere and plant nutrition: A quantitative approach", Plant and Soil, 155/156. 1-20. 1993.

[122] Gahoonia, T.S., Claassen, N. and Jungk, A, "Mobilization of phosphate in different soils by ryegrass supplied with ammonium or nitrate", Plant and Soil, 140. 241-48. 1992.

[123] Gardener, W.K., Parbery, D.G. and Barber, D.A, "The acquisition of phosphorus by Lupinus albus L. II. The effect of varying phosphorus supply and soil type on some characteristics of the soil/ root interface", Plant and Soil, 68. 33-41. 1982.

[124] Jones, D.L. and Darrah, P.R, "Role of root derived organic acids in the mobilization of nutrients from the rhizosphere", Plant and Soil, 166. 247-257. 1994.

[125] Seeling, B. and Jungk, A, "Utilization of organic phosphorus in calcium chloride Extracts of soil by barley plants and hydrolysis by acid and alkaline phosphatases", Plant and Soil, 178. 179-84. 1996. 